ARTICLE

https://doi.org/10.1038/s41467-019-12939-3

\title{
Structural water and disordered structure promote aqueous sodium-ion energy storage in sodium-birnessite
}

\author{
Xiaoqiang Shan (10 1, Fenghua Guo', Daniel S. Charles', Zachary Lebens-Higgins (i) 2, Sara Abdel Razek², \\ Jinpeng $\mathrm{Wu}^{3}$, Wenqian $\mathrm{Xu}^{4}$, Wanli Yang (1) ${ }^{3}$, Katharine L. Page (i) ${ }^{5}$, Joerg C. Neuefeind (1) ${ }^{5}$, \\ Mikhail Feygenson (10) 5,6 , Louis F.J. Piper (1) ${ }^{2} \&$ Xiaowei Teng (i]) ${ }^{1 \star}$
}

Birnessite is a low-cost and environmentally friendly layered material for aqueous electrochemical energy storage; however, its storage capacity is poor due to its narrow potential window in aqueous electrolyte and low redox activity. Herein we report a sodium rich disordered birnessite $\left(\mathrm{Na}_{0.27} \mathrm{MnO}_{2}\right)$ for aqueous sodium-ion electrochemical storage with a much-enhanced capacity and cycling life ( $83 \mathrm{mAh} \mathrm{g}^{-1}$ after 5000 cycles in full-cell). Neutron total scattering and in situ X-ray diffraction measurements show that both structural water and the Na-rich disordered structure contribute to the improved electrochemical performance of current cathode material. Particularly, the co-deintercalation of the hydrated water and sodium-ion during the high potential charging process results in the shrinkage of interlayer distance and thus stabilizes the layered structure. Our results provide a genuine insight into how structural disordering and structural water improve sodium-ion storage in a layered electrode and open up an exciting direction for improving aqueous batteries.

\footnotetext{
${ }^{1}$ Department of Chemical Engineering, University of New Hampshire, Durham, NH 03824, USA. ${ }^{2}$ Department of Physics, Applied Physics and Astronomy, Binghamton University, Binghamton, NY 13902, USA. ${ }^{3}$ Advanced Light Source, Lawrence Berkeley National Laboratory, Berkeley, CA 94720, USA.

${ }^{4}$ Advanced Photon Source, Argonne National Laboratory, Argonne, IL 60439, USA. ${ }^{5}$ Chemical and Engineering Materials Division, Spallation Neutron Source, Oak Ridge National Laboratory, Oak Ridge, TN 37831, USA. ${ }^{6}$ Juelich Centre for Neutron Science, Forschungszentrum Juelich GmbH, 52425 Juelich, Germany. *email: xw.teng@unh.edu
} 
lectrochemical energy storage (EES) using earth-abundant materials has become attractive for storing electric energy generated by solar and wind ${ }^{1}$. Aqueous EES using sodium (Na)-ion as charge carrier is promising alternative to nonaqueous lithium (Li)-ion batteries (LIBs) owing to low cost, high safety and the availability of $\mathrm{Na}$ sources in terrestrial reserves ${ }^{2}$. However, $\mathrm{Na}$-ion storage is challenging for its large radius. Consequently, LIB host materials (especially cathode) that typically have a close-packed array of oxide ions are able to reversibly accommodate $\mathrm{Na}$-ions. Two design principles are used to tackle the issue. One is to replace oxygen anions $\left(\mathrm{O}^{2-}\right)$ with anions having weaker bonding with metal cations so that cations are sufficiently mobile in the electrode. Recent studies show promise of hexacyano ion $(\mathrm{C} \equiv \mathrm{N})_{6}{ }^{6-}$ based electrode materials for $\mathrm{Na}$ - and $\mathrm{K}$-ion storage due to the weakened bonding between cyanide $(\mathrm{C} \equiv \mathrm{N})^{-}$and cations. Cui and co-workers have demonstrated that potassium copper hexacyanoferrate and its analogues can function as stable electrode materials for aqueous $\mathrm{K}$ - and $\mathrm{Na}$-ion storage $^{3-5}$. Sodium-manganese hexacyanoferrate reported by Goodenough's group showed good energy performance and cycling life in a non-aqueous electrolyte $\mathrm{e}^{6-8}$. Another approach is to use a large interstitial host framework, especially layered structure. Layered materials with planar or zigzag layers show different polymorphs ( $\mathrm{P} 2, \mathrm{P} 3$ or $\mathrm{O} 2, \mathrm{O} 3$ phase) with respect to the sites of intercalated $\mathrm{Na}$-ion by simply altering the stacking of transition-metal-oxygen octahedra ${ }^{9-11}$. Pioneer works on studying $\mathrm{Na}$-ion intercalation in layered $\mathrm{Na}_{\mathrm{x}} \mathrm{MnO}_{2}$ were reported by Hagenmuller in the $1980 \mathrm{~s}^{12,13}$. However, the mechanistic understanding of Na-ion storage inside various host materials is still not settled. Size difference between $\mathrm{Na}$-ion and Li-ion gives rise to different intercalation chemistries ${ }^{14}$, so that the understanding obtained from Li-ion storage may not be directly applied to the Na-ion electrodes ${ }^{15-18}$. In addition, layered $\mathrm{Na}_{\mathrm{x}} \mathrm{MnO}_{2}$ especially $\mathrm{P}$-type materials where $\mathrm{Na}$-ions occupy trigonal prismatic site suffer from $\mathrm{P} 2-\mathrm{O} 2$ phase transition during charging with a large lattice collapse and up to $23 \%$ of volume shrinkage, resulting in an increased Na-ion diffusion barrier and rapid capacity decay ${ }^{19,20}$.

Birnessite $\left(\delta-\mathrm{MnO}_{2}\right)$ is a layered structure comprised of twodimensional sheets of edge-sharing $\mathrm{MnO}_{6}$ octahedra with intercalated cations and/or water in the interlayer ${ }^{21-25}$. Although birnessite has a large interlayer distance $(\sim 7 \AA)$, its storage capacities for $\mathrm{Na}$-ion were low due to the limited thermodynamically stable potential window $(\sim 1.23 \mathrm{~V})$ of an aqueous electrolyte and ineffective redox process ${ }^{26-28}$. Recent studies showed that a concentrated Li-bis(trifluoromethane sulfonyl) imide salt in water electrolyte helped the formation of an electrode-electrolyte interphase on a $\mathrm{Mo}_{6} \mathrm{~S}_{8}$ anode that prevented the direct contact between anode and water, thus achieved potential window of $3.0 \mathrm{~V}$ for aqueous $\mathrm{EES}^{29}$. A similar wide potential window was reported for aqueous electrolyte using hydrate-melt of $\mathrm{Li}$ salts ${ }^{30,31}$. However, little work has been reported to date on how to widen the potential window of birnessite electrode materials in aqueous electrolytes.

Here we present an effective strategy to significantly improve the discharge capacity and cycle life of birnessite (full-cell capacity of $83 \mathrm{mAh} \mathrm{g}^{-1}$ at $1 \mathrm{Ag}^{-1}$ after 5000 cycles) through increasing the stable potential window and promoting redox charge transfer process towards aqueous $\mathrm{Na}$-ion storage. Our results demonstrate that $\mathrm{Na}$-rich and disordered birnessite structure can afford a stable potential window of $2.5 \mathrm{~V}$ in an aqueous electrolyte with high overpotential towards the gas evolution reactions. Moreover, co-deintercalation of water molecules along with $\mathrm{Na}$-ion at the high potential charging, evidenced by in situ XRD, can stabilize the layered structure from over-expansion of the interlayer distance.

\section{Results}

Structural characterizations and formation mechanism. Different from wet chemistry synthesis of birnessite $24,25,27,32$, disordered and Na-rich birnessite were prepared at $270{ }^{\circ} \mathrm{C}$ in air via a solid-state reaction between $\mathrm{NaOH}$ and $\mathrm{Mn}_{3} \mathrm{O}_{4}$ nanoparticles $\left(\mathrm{Mn}_{3} \mathrm{O}_{4}\right.$ particles were synthesized using a method reported previously ${ }^{33}$ ). By altering the molar ratios between $\mathrm{NaOH}$ and $\mathrm{Mn}_{3} \mathrm{O}_{4}$, sodium-intercalated manganese oxides $\left(\mathrm{Na}_{\delta} \mathrm{MnO}_{\mathrm{x}} ; \delta\right.$ : $0.10,0.17$, and 0.27 ) were prepared, verified by Inductively Coupled Plasma Mass Spectrometry (ICP-MS) (Supplementary Table 1). The $\mathrm{Na} / \mathrm{Mn}$ ratio remained around 0.27 even when a higher $\mathrm{NaOH} / \mathrm{Mn}_{3} \mathrm{O}_{4}$ ratio of 4 was used (Supplementary Figure 1). The $\mathrm{Na} / \mathrm{Mn}$ ratio of 0.27 is higher than those of birnessite

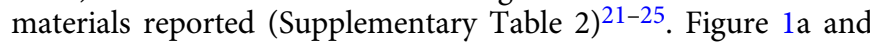
Supplementary Fig. 2 show that as $\mathrm{Na}$ concentrations increased from 0.10 to 0.27 , the morphologies of resulting $\mathrm{Na}-\mathrm{Mn}-\mathrm{O}$ materials evolved from a mixture of faceted particles and planar structures to a complete planar structure. The atomic ordering of the resulting $\mathrm{Na}-\mathrm{Mn}-\mathrm{O}$ materials was analyzed using neutron total scattering and the atomic pair distribution function (PDF) (Fig. 1b), from which both the Bragg and diffuse scattering were analyzed to provide local structural details such as defects, mismatch or disorder at the atomic level. The structural parameters of various $\mathrm{Na}_{\delta} \mathrm{MnO}_{\mathrm{x}}$ materials obtained from refinement are summarized in Supplementary Fig. 3 and Supplementary Table 3-6. The neutron PDF showed that the coherent length of
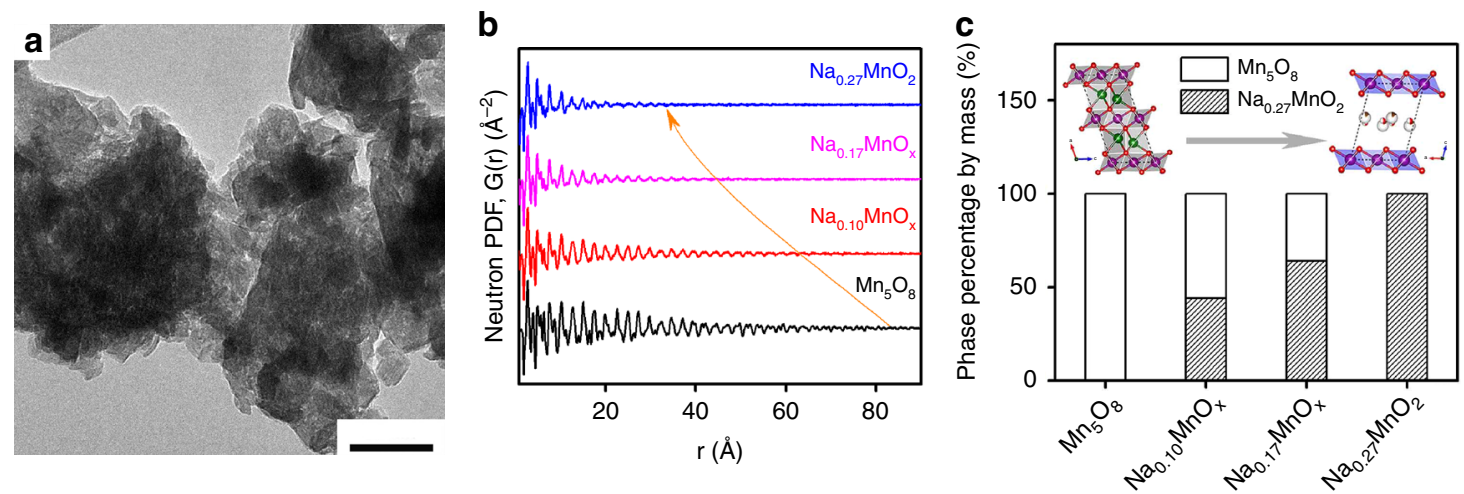

Fig. 1 TEM and neutron PDF analysis of sodium-manganese oxides. a TEM image of of $\mathrm{Na}_{0.27} \mathrm{MnO}_{2}$ materials; scale bar, $50 \mathrm{~nm}$; $\mathbf{b}$ Experimental neutron PDFs of $\mathrm{Na}_{\delta} \mathrm{MnO}_{x}$ materials, where coherent lengths, defined as the longest interatomic distance of the material, decreased as the Na concentration increased; c Phase percentage of $\mathrm{Na}_{0.27} \mathrm{MnO}_{2}$ in $\mathrm{Na}_{\delta} \mathrm{MnO}_{x}$ materials obtained from neutron PDF analysis 


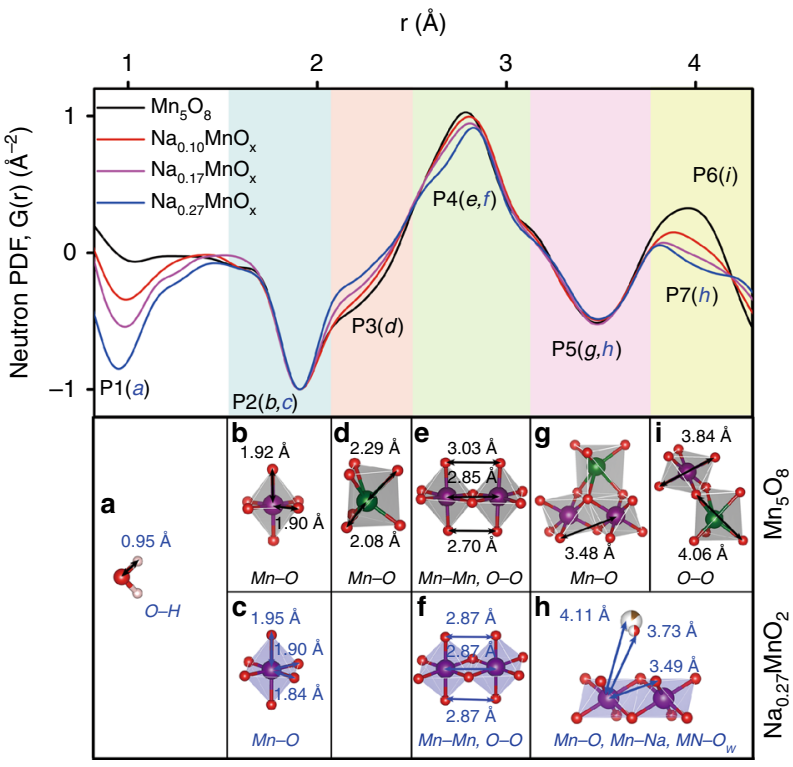

Fig. 2 Neutron PDFs of various $\mathrm{Na}_{\delta} \mathrm{MnO}_{x}$ materials. The atom pair associated with each peak (P1 to P7) can be attributed to a water, b, d, e, $\mathbf{g}$, i $\mathrm{Mn}_{5} \mathrm{O}_{8}$ polyhedra in black and $\mathbf{c}, \mathbf{f}, \mathbf{h} \mathrm{MnO}_{2}$ polyhedra in blue

$\mathrm{Na}_{\delta} \mathrm{MnO}_{\mathrm{x}}$ materials (a distance at which the peaks of atomic pairs vanished) decreased from $>50 \AA$ to $\sim 30 \AA$ as $\delta$ increases, indicating more confined crystalline order. Namely, $\mathrm{Na}_{\delta} \mathrm{MnO}_{\mathrm{x}}$ materials cannot sustain long-range crystallinity and became more disordered when more $\mathrm{Na}$-ions are incorporated into the structure. Figure $1 \mathrm{c}$ shows that as $\mathrm{Na}$ concentration $(\delta)$ increased, $\mathrm{Na}_{\delta} \mathrm{MnO}_{\mathrm{x}}$ materials showed pure phase $\mathrm{Mn}_{5} \mathrm{O}_{8}(\delta=0)$, mixture of $\mathrm{Mn}_{5} \mathrm{O}_{8}$ and layered $\mathrm{MnO}_{2}(\delta=0.10$ and 0.17$)$. When $\delta$ reached 0.27 , a pure triclinic birnessite structure formed with an interplanar distance of $7.19 \AA$. The chemical formula was determined as $\mathrm{Na}_{0.27} \mathrm{MnO}_{2} \cdot 0.63 \mathrm{H}_{2} \mathrm{O}$, where the $\mathrm{Na}^{+}$and structural water (determined from thermal gravimetric analysis shown in Supplementary Fig. 5) occupied the interlayers.

Neutron PDF studied the evolution of local structure during the transition from $\mathrm{Mn}_{3} \mathrm{O}_{4}$ to $\mathrm{Mn}_{5} \mathrm{O}_{8}$, and finally to $\mathrm{MnO}_{2}$ birnessite (Fig. 2). The PDF data were normalized by the intensity of the peak at $1.9 \AA$ to see the comparative changes of the structural details as $\delta$ increased, and the original coherent scattering and structure factor data can be found in Supplementary Fig. 6. The peaks of PDF can be indexed as O-H pair $(0.95 \AA$, $\mathrm{P} 1)$ from water $(a)$, one $\mathrm{Mn}-\mathrm{O}$ pair $\left(1.9 \AA\right.$, P2) from the $\left[\mathrm{MnO}_{6}\right]$ octahedral unit and another Mn-O pair (2.2 $\mathrm{A}, \mathrm{P} 3)$ from $\mathrm{Mn}$ atoms in prismatic sites, $\mathrm{Mn}-\mathrm{Mn}$ or $\mathrm{O}-\mathrm{O}$ pair (2.8 $\AA$, P4), and $\mathrm{Mn}-\mathrm{O}$ pair (3.5 $\AA$, P5) from the nearest neighbors of $\left[\mathrm{MnO}_{6}\right]$ octahedral units, respectively. The contribution of individual pairs such as $\mathrm{Mn}-\mathrm{O}, \mathrm{Mn}-\mathrm{Mn}, \mathrm{O}-\mathrm{O}$, and $\mathrm{Mn}-\mathrm{Na}$, to the overall PDF of the materials can be found in Supplementary Figure 7. Notably O-H pair (P1) and $\mathrm{Mn}-\mathrm{O}$ pairs (P2, P3, P5, and P7) showed negative peaks due to negative coherent neutron scattering lengths of $\mathrm{H}$ and $\mathrm{Mn}$ atoms ( -3.74 and -3.73 femtometer, respectively). The $\mathrm{Mn}-\mathrm{O}$ pair (1.9 $\AA$, P2) is attributed to $\mathrm{Mn}-\mathrm{O}$ octahedral coordination in both $\mathrm{Mn}_{5} \mathrm{O}_{8}(b)$ and layered $\mathrm{Na}_{0.27} \mathrm{MnO}_{2}$ (c) structures. The $\mathrm{Mn}-\mathrm{O}$ pair $(2.2 \AA$, P3) is attributed to $\mathrm{Mn}(\mathrm{II})-\mathrm{O}$ from $\mathrm{Mn}_{5} \mathrm{O}_{8}$ phase $(d)$, which decreased relatively to $\mathrm{Mn}(\mathrm{IV})-\mathrm{O}$ pair at $\mathrm{P} 2$ as $\delta$ increased, congruent with the decreasing phase fractions of $\mathrm{Mn}_{5} \mathrm{O}_{8}$. The positive peaks at $2.8 \AA(\mathrm{P} 4)$ are attributed to $\mathrm{Mn}-\mathrm{Mn}$ or $\mathrm{O}-\mathrm{O}$ bonding from adjacent $\left[\mathrm{MnO}_{6}\right]$ octahedral units in $\mathrm{Mn}_{5} \mathrm{O}_{8}(e)$ and $\mathrm{Na}_{0.27} \mathrm{MnO}_{2}(f)$ relative to the $\mathrm{Mn}(\mathrm{IV})-\mathrm{O}$ pair, which did not change significantly as $\delta$ increased. A similar trend can be found in the Mn-O pair at $3.5 \AA$ (P5) from adjacent $\left[\mathrm{MnO}_{6}\right]$ in $\mathrm{Mn}_{5} \mathrm{O}_{8}$ $(g)$ and $\mathrm{Na}_{0.27} \mathrm{MnO}_{2}$ phases $(h)$. The peaks at $\sim 4.0 \AA$ (P6 and P7) showed a rather interesting transition from positive to negative direction as $\delta$ increased. The positive peak at $3.96 \AA$ (P6) is related to $\mathrm{O}-\mathrm{O}$ pairs $(i)$ in $\mathrm{Mn}_{5} \mathrm{O}_{8}$ either within the same [Mn $(\mathrm{IV}) \mathrm{O}_{6}$ ] octahedral unit or [Mn(II)-O] units where $\mathrm{Mn}^{2+}$ is located in the trigonal prismatic site. In contrast, the negative peak at $4.0 \AA(\mathrm{P} 7)$ is attributed to $\mathrm{Mn}-\mathrm{Na}$ pair at $4.11 \AA(h)$ from the interaction between $\mathrm{Na}$-ions in interlayers and $\mathrm{Mn}^{4+}$ from $\left[\mathrm{MnO}_{6}\right]$ octahedra or $\mathrm{Mn}-\mathrm{O}_{\mathrm{w}}$ pair $\left(\mathrm{O}_{\mathrm{w}}\right.$ from structural water in the interlayer) at $3.73 \AA(h)$ from the interaction between $\mathrm{H}_{2} \mathrm{O}$ in interlayers and $\mathrm{Mn}^{4+}$, both from $\mathrm{Na}_{0.27} \mathrm{MnO}_{2}$ layered phase. The interplay between negative peaks of $\mathrm{Mn}-\mathrm{Na}$ and $\mathrm{Mn}-\mathrm{O}_{\mathrm{W}}$ in $\mathrm{Na}_{0.27} \mathrm{MnO}_{2}$ and the positive peak of $\mathrm{O}-\mathrm{O}$ in $\mathrm{Mn}_{5} \mathrm{O}_{8}$ at around $4.0 \AA$ explains the overall peak change from positive to negative directions when $\delta$ increased. This suggests that phase transition from $\mathrm{Mn}_{5} \mathrm{O}_{8}$ to $\mathrm{Na}_{0.27} \mathrm{MnO}_{2}$ birnessite was driven by $\mathrm{Na}$-ion insertion during solid-state annealing.

From neutron PDF and in situ XRD during the thermal treatment (Supplementary Fig. 8), a formation mechanism of $\mathrm{Na}_{0.27} \mathrm{MnO}_{2}$ birnessite is proposed in Fig. 3. $\mathrm{Mn}_{3} \mathrm{O}_{4}$ nanoparticles were first converted into $\mathrm{Mn}_{5} \mathrm{O}_{8}$ materials through oxidation of [Mn(III)O $\mathrm{O}_{6}$ octahedra of $\mathrm{Mn}_{3} \mathrm{O}_{4}$ into [Mn (IV)O $\mathrm{O}_{6}$ ] units, followed by $\mathrm{Na}$-ion driven conversion from $\mathrm{Mn}_{5} \mathrm{O}_{8}$ to $\mathrm{Na}_{0.27} \mathrm{MnO}_{2}$ birnessite during the thermal annealing in air. $\mathrm{Mn}_{5} \mathrm{O}_{8}$ and $\mathrm{Na}_{0.27} \mathrm{MnO}_{2}$ share similar structural characteristics: $\mathrm{Mn}_{5} \mathrm{O}_{8}$ has a layered structure and consists of sheets of $\left[\mathrm{Mn}_{3}^{4+} \mathrm{O}_{8}\right]^{4-}$ in the $b c$ plane. The $\left[\mathrm{Mn}_{3}^{4+} \mathrm{O}_{8}\right]^{4-}$ sheets resemble the structure of $\mathrm{Na}_{0.27} \mathrm{MnO}_{2}$ birnessite comprised of infinite $\left[\mathrm{MnO}_{6}\right]$ octahedral layers with intercalated $\mathrm{Na}$ cations in between. The transition from $\mathrm{Mn}_{5} \mathrm{O}_{8}$ to $\mathrm{Na}_{0.27} \mathrm{MnO}_{2}$ birnessite is an equivalent process to the ion-exchange of $\mathrm{Mn}^{2+}$ ions in the $\mathrm{Mn}_{2}^{2+} \mathrm{Mn}_{3}^{4+} \mathrm{O}_{8}$ with $\mathrm{Na}^{+}$ions in the solid state. Our result suggests that $\mathrm{Mn}^{2+}$ ions with trigonal prismatic coordination located in interlayers of $\mathrm{Mn}_{5} \mathrm{O}_{8}$ have a higher mobility than octahedrally coordinated $\mathrm{Mn}^{4+}$ ions. Therefore, insertion of $\mathrm{Na}$ ions into the $\mathrm{Mn}^{2+}$ site was kinetically favored, accompanied by the oxidation of $\mathrm{Mn}^{2+}$ ions into $\mathrm{Mn}^{4+}$ during the migration of $\mathrm{Mn}^{2+}$ to the $\left[\mathrm{Mn}^{4+}{ }_{3} \mathrm{O}_{8}\right]^{4-}$ layers, and drove the formation of $\mathrm{Na}_{0.27} \mathrm{MnO}_{2}$. XRD showed that anhydrous $\mathrm{Na}_{0.27} \mathrm{MnO}_{2}$ has an interlayer distance of $5.6 \AA$ (Supplementary Fig. 9), similar to that of $\mathrm{Mn}_{5} \mathrm{O}_{8}$ (5.2 $\AA$ ). Upon water intercalation, $\mathrm{Na}_{0.27} \mathrm{M}$ $\mathrm{nO}_{2} \cdot 0.63 \mathrm{H}_{2} \mathrm{O}$ showed an increased interlayer distance of $7.19 \AA^{34}$. $\mathrm{Na}$-ion driven conversion from $\mathrm{Mn}_{5} \mathrm{O}_{8}$ to $\mathrm{Na}_{0.27} \mathrm{MnO}_{2}$ reported here contrasts the formation of $\mathrm{Li}-\mathrm{MnO}_{2}$ via the ion-exchange between $\mathrm{Ca}_{2} \mathrm{Mn}_{3} \mathrm{O}_{8}\left(\mathrm{Ca}^{2+}{ }_{2} \mathrm{Mn}^{4+}{ }_{3} \mathrm{O}_{8}\right)$, isomorphic structure of $\mathrm{Mn}_{5} \mathrm{O}_{8}\left(\mathrm{Mn}^{2+}{ }_{2} \mathrm{Mn}^{4+}{ }_{3} \mathrm{O}_{8}\right)$, and molten lithium nitrate ${ }^{35}$. In the formation of $\mathrm{Li}-\mathrm{MnO}_{2}$, $\mathrm{Li}$-ions occupied all the available octahedral sites between the $\left[\mathrm{Mn}_{3}^{4+} \mathrm{O}_{8}\right]^{4-}$ layers rather than the trigonal prismatic sites occupied by $\mathrm{Ca}^{2+}$ in the parent $\mathrm{Ca}_{2} \mathrm{Mn}_{3} \mathrm{O}_{8}$ compound due to much smaller size of $\mathrm{Li}^{+}$compared with $\mathrm{Ca}^{2+}$, resulting in the complete conversion to layered $\mathrm{LiMnO}_{2}$ with $\mathrm{R} \overline{3} \mathrm{~m}$ or $\mathrm{O} 3$ symmetry.

Electrochemical properties. Electrochemical performance of various $\mathrm{Na}_{\delta} \mathrm{MnO}_{\mathrm{x}}$ materials was tested in a $0.1 \mathrm{M} \mathrm{Na}_{2} \mathrm{SO}_{4}$ electrolyte in a three-electrode half-cell using cyclic voltammetry (CV) between $-1.25 \mathrm{~V}$ and $1.25 \mathrm{~V}$ (vs Ag/AgCl) (Supplementary Fig. 10). Figure $4 \mathrm{a}$ shows the $\mathrm{CVs}$ of disordered Na-rich $\mathrm{Na}_{0.27} \mathrm{MnO}_{2}$, where distinct redox peaks can be observed at all the tested scan rates. Figure $4 \mathrm{a}$ shows that when scan rate increased, $\mathrm{Na}_{0.27} \mathrm{MnO}_{2}$ shows small peak shifts in the anodic process $(0.12 \mathrm{~V})$ and the cathodic process $(0.14 \mathrm{~V})$, compared with the other $\mathrm{Na}_{\delta} \mathrm{MnO}_{x}$ materials (Supplementary Fig. 11), indicating Na-ion transport in $\mathrm{Na}_{0.27} \mathrm{MnO}_{2}$ required a lower 


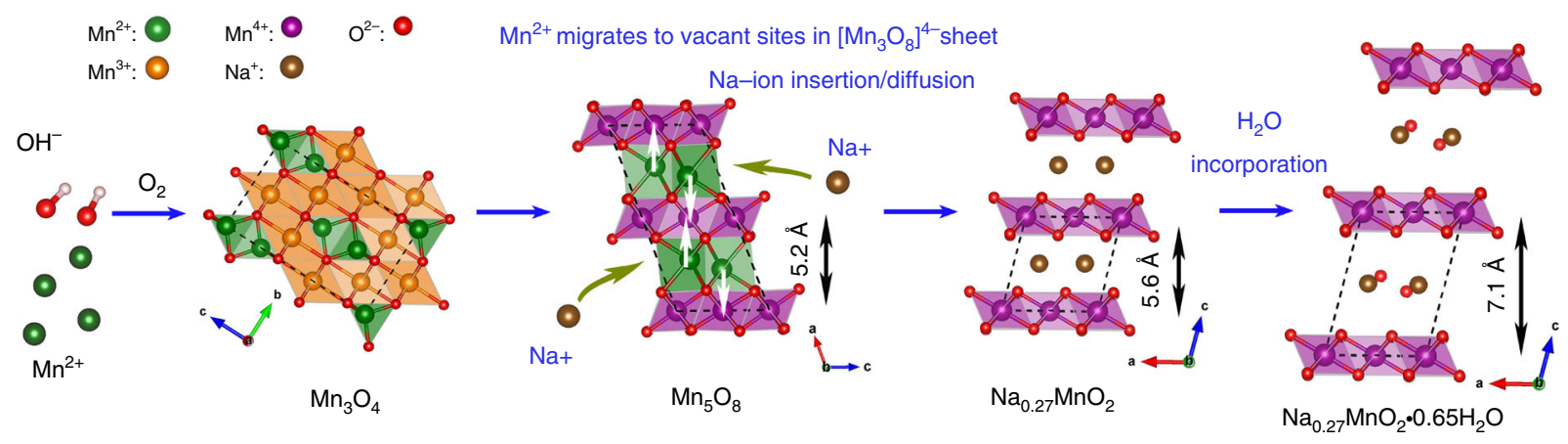

Fig. 3 The schematic of the formation mechanism. The proposed Na-ion driven intercalation in the formation of $\mathrm{Na}_{0.27} \mathrm{MnO}_{2} \cdot 0.65 \mathrm{H}_{2} \mathrm{O}$ materials in solidstate $\left(\mathrm{Mn}^{2+}\right.$ : green; $\mathrm{Mn}^{3+}$ : orange; $\mathrm{Mn}^{4+}$ : purple; $\mathrm{Na}^{+}$: brown; O: red)

a

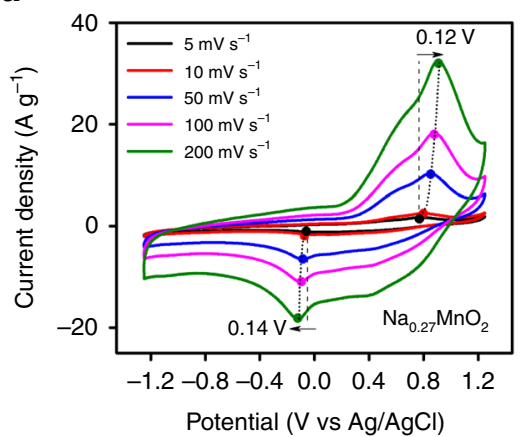

d

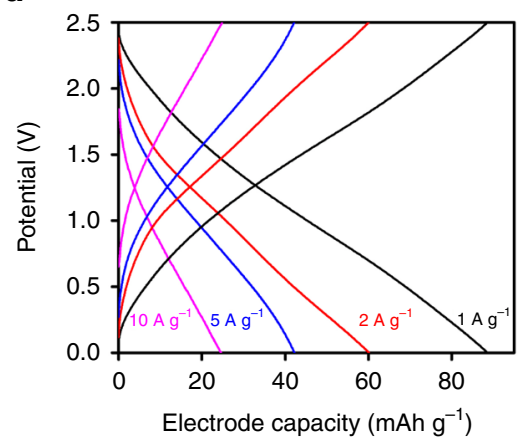

b

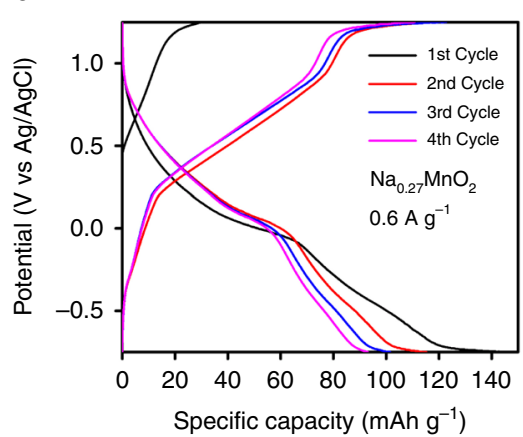

e

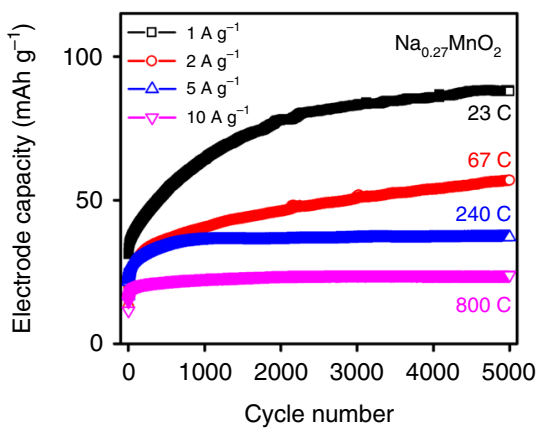

C

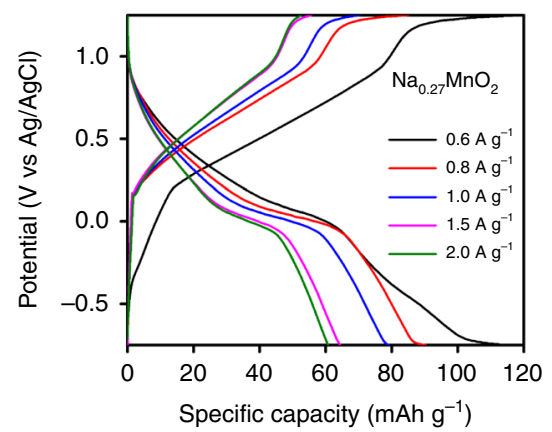

f

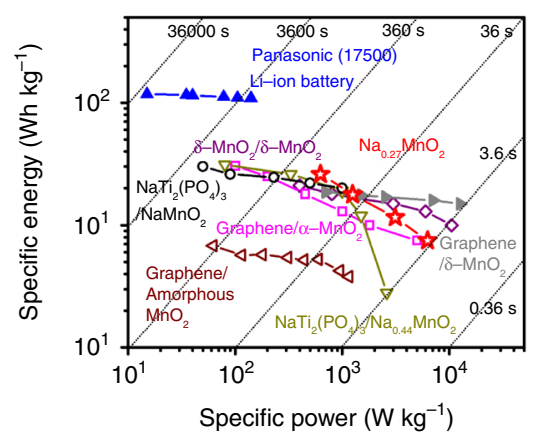

Fig. 4 Electrochemical measurements of $\mathrm{Na}_{0.27} \mathrm{MnO}_{2}$ in half-cells and full-cells. Electrochemical half-cell measurements with a $\mathrm{CV}$ scans of $\mathrm{Na}_{0.27} \mathrm{MnO}_{2}$ material between $-1.25 \mathrm{~V}$ and $1.25 \mathrm{~V}$ (vs Ag/AgCl) at various scan rates in $0.1 \mathrm{M} \mathrm{Na}_{2} \mathrm{SO}_{4}$ electrolyte; $\mathbf{b} \mathrm{CP}$ tests of $\mathrm{Na}_{0.27} \mathrm{MnO}_{2} \mathrm{material}_{\text {between }}-0.75 \mathrm{~V}$ and $1.25 \mathrm{~V} \mathrm{(vs} \mathrm{Ag/AgCl}$ ) at a current density of $0.6 \mathrm{Ag}^{-1}$ in $0.1 \mathrm{M} \mathrm{Na}_{2} \mathrm{SO}_{4}$ electrolyte with the intial four charge and discharge cycles c CP tests of $\mathrm{Na}_{0.27} \mathrm{MnO}_{2}$ material between $-0.75 \mathrm{~V}$ to $1.25 \mathrm{~V}$ ( $\mathrm{vs} \mathrm{Ag} / \mathrm{AgCl}$ ) at current densities ranging from 0.6 to $2.0 \mathrm{Ag}^{-1}$ in $0.1 \mathrm{M} \mathrm{Na}_{2} \mathrm{SO}_{4}$ electrolyte $(2 \mathrm{nd}$ cycle data). Symmetric full-cell measurements with $\mathbf{d}$ charge and discharge electrode capacities of $\mathrm{Na}_{0.27} \mathrm{MnO}_{2}$ material at the various current densities of $1 \mathrm{Ag}-1$, $2 \mathrm{Ag}^{-1}, 5 \mathrm{Ag}^{-1}$, and $10 \mathrm{Ag}^{-1}$ (after 5000 galvonstatic charge and discharge process unless specified otherwise); e electrode capacities of $\mathrm{Na}_{0.27} \mathrm{MnO}_{2}$ as a function of cycle number up to 5000 at the current densities from $1 \mathrm{Ag}^{-1}$ to $10 \mathrm{Ag}^{-1}$; f Ragone plot with gravimetric specific energy and power of the symmetric $\mathrm{Na}_{0.27} \mathrm{MnO}_{2}$ full-cell after 5000 galvanostatic cycles. The aqueous (empty symbols) and non-aqueous (solid symbols) devices are reported, and the gravimetric specific energy and power are calculated by the mass of electrode materials except the Panasonic (17500) Li-ion batteries

overpotential at higher charging rates. Further quantitative evaluation of $\mathrm{Na}$-ion transport in all $\mathrm{Na}_{\delta} \mathrm{MnO}_{x}$ materials was obtained using a current-pulse relaxation $\operatorname{method}^{13}$, where the $\mathrm{Na}_{0.27} \mathrm{MnO}_{2}$ material showed a highest diffusion coefficient of 38.7 (relative to $\mathrm{Mn}_{5} \mathrm{O}_{8}$ ) than the other $\mathrm{Na}_{\delta} \mathrm{MnO}_{\mathrm{x}}$ materials (Supplementary Figure 12). This result was congruent with $\mathrm{CV}$ data, where $\mathrm{Na}_{0.27} \mathrm{MnO}_{2}$ had the lowest energy barrier for $\mathrm{Na}$-ion intercalation since it had a more dominant phase of layered birnessite.

Figure $4 \mathrm{~b}$ shows the galvanostatic chronopotentiometry (CP) tests of $\mathrm{Na}_{0.27} \mathrm{MnO}_{2}$ materials in half-cell at $0.6 \mathrm{~A} \mathrm{~g}^{-1}$ under the potential window between $-0.75 \mathrm{~V}$ and $1.25 \mathrm{~V}$ (vs $\mathrm{Ag} / \mathrm{AgCl}$ ), demonstrating a high discharge capacity of $138 \mathrm{mAh} \mathrm{g}^{-1}$ (1st cycle) and a capacity of $94 \mathrm{mAh} \mathrm{g}^{-1}$ after 4 th cycle. A highest discharge capacity of $144 \mathrm{mAh}^{-1}$ was observed for $\mathrm{Na}$-ion storage at a current density of $0.3 \mathrm{~A} \mathrm{~g}^{-1}$ (Supplementary Fig. 13), although additional capacity could be attributed to the hydrogen evolution reaction (HER). It is suggested that discharge capacity of $144 \mathrm{mAh} \mathrm{g}^{-1}$ could be the highest capacity of $\mathrm{Na}_{0.27} \mathrm{MnO}_{2}$ materials measured at three-electrode half-cell conditions, corresponding to $0.47 \mathrm{Na}$-ion transfer per $\mathrm{Mn}$ atom. As $\mathrm{Na}_{0.27} \mathrm{MnO}_{2}$ electrode materials was initially charged to $1.25 \mathrm{~V}$ from open circuit voltage of $\sim 0.5 \mathrm{~V}$ with the 1st cycle charge capacity of $71 \mathrm{mAh} \mathrm{g}^{-1}$, indicating a roughly $0.23 \mathrm{Na}$-ion removal. In the 
following 1st cycle discharge process, the $\mathrm{MnO}_{2}$ birnessite electrode displayed a discharge capacity about $144 \mathrm{mAh} \mathrm{g}^{-1}$, pointing to $0.47 \mathrm{Na}$-ion insertion. Figure $4 \mathrm{c}$ shows $\mathrm{CPs}$ of $\mathrm{Na}_{0.27} \mathrm{MnO}_{2}$ in the three-electrode half-cell at current densities from $0.6 \mathrm{Ag}^{-1}$ to $2 \mathrm{~A} \mathrm{~g}^{-1}$. As current densities increased, discharged capacities decreased from 115 to $61 \mathrm{mAh} \mathrm{g}^{-1}$. Moreover, Supplementary Figure 14 shows that the charge and discharge potential differences at the midpoint of the capacity increased from $0.65 \mathrm{~V}$ to $0.75 \mathrm{~V}$ as current densities increased, suggesting an increasing polarization for $\mathrm{Na}$-ion transport, comparable to the values reported in $\mathrm{Zn}-\mathrm{MnO}_{2}{ }^{36-38}$, $\mathrm{Na}-\mathrm{MnO}_{2}{ }^{39}$, and $\mathrm{Li}_{2} \mathrm{Mn}_{2 / 3} \mathrm{Nb}_{1 / 3} \mathrm{O}_{2} \mathrm{~F}$ system ${ }^{40}$, reflecting the intrinsic redox barrier for the $\mathrm{MnO}_{2}$ based electrode systems.

Supplementary Figure 15 shows X-ray photoelectron spectroscopy (XPS) spectra of $\mathrm{Na}_{0.27} \mathrm{MnO}_{2}$. The pristine state $\mathrm{Mn}$ showed a dominant $\mathrm{Mn}^{4+}$ state with characteristic $\mathrm{Mn} 2 \mathrm{p}_{1 / 2}$ and Mn $2 \mathrm{p}_{3 / 2}$ features at $654.2 \mathrm{eV}$ and $642.5 \mathrm{eV}$, and less distinct but discernable $\mathrm{Mn}^{3+}$ features at $642.2 \mathrm{eV}$ and $653.3 \mathrm{eV}$, respectively (Supplementary Fig. 16). The ratio between $\mathrm{Mn}^{4+}$ and $\mathrm{Mn}^{3+}$ was calculated to be $0.72: 0.28$. Since the $\mathrm{Mn}^{3+}$ resulted from the intercalated $\mathrm{Na}$-ion in interlayers of $\mathrm{MnO}_{2}$, a $\mathrm{Mn}^{4+} / \mathrm{Mn}^{3+}$ ratio of $0.72: 0.28$ suggested a $\mathrm{Na} / \mathrm{Mn}$ ratio of 0.28 , nearly identical to the ICP-MS result $(\mathrm{Na}: \mathrm{Mn}=0.27)$. At charged state $(1.25 \mathrm{~V})$ $\mathrm{Na}_{0.27} \mathrm{MnO}_{2}$ showed a $\mathrm{Mn}^{4+} / \mathrm{Mn}^{3+}$ ratio of $0.97: 0.03$, and a $\mathrm{Mn}^{4+} / \mathrm{Mn}^{3+}$ ratio of $0.62: 0.38$ at discharged state $(-1.25 \mathrm{~V})$. Although the exact determination of $\mathrm{Mn}^{2+/ 3+/ 4+}$ ratio is challenging from the $\mathrm{Mn} 2 \mathrm{p}$ core region due to the multiplet structure and significant overlap between different oxidation states, XPS results confirmed that $\mathrm{Na}_{0.27} \mathrm{MnO}_{2}$ materials had a $\mathrm{Mn}^{4+} / \mathrm{Mn}^{3+}$ redox couple during insertion and extraction of Na-ions.

We also analyzed the current $(i)$ at different scan rates $(v)$ at a given potential, assuming that the total current $(i)$ at a particular potential contains both capacitive current $\left(i_{1}=k_{1} v\right)$ and diffusion-limited redox current $\left(i_{2}=k_{2} v^{1 / 2}\right):{ }^{41}$

$$
i=i_{1}+i_{2}=k_{1} v+k_{2} v^{1 / 2} \text { or } i / v^{1 / 2}=k_{1} v^{1 / 2}+k_{2}
$$

The values of $k_{1}$ and $k_{2}$ and] the relative current response from $i_{1}$ and $i_{2}$ can be obtained. The CVs marked with capacitive and diffusion-limited redox contributions at scan rates ranging from 5 to $1000 \mathrm{mV} \mathrm{s}^{-1}$ can be found and summarized in Supplementary Figs. 17 and 18 .

Long-term performance of $\mathrm{Na}_{0.27} \mathrm{MnO}_{2}$ was tested in symmetric full-cells in a potential window of $2.5 \mathrm{~V}$. Toray paper was used as the current collector without causing gas evolution reactions (Supplementary Fig. 19). Figure 4d and Supplementary Fig. 20 show that voltage-capacity profiles are nearly linear at all the tested current densities, pointing to a single-phase solid solution reaction. Accordingly, electrode capacities were calculated to be $83 \mathrm{mAh} \mathrm{g}^{-1}$ to $24 \mathrm{mAh} \mathrm{g}^{-1}$ at corresponding discharge times ranging from $160 \mathrm{~s}$ to $4.5 \mathrm{~s}$. Moreover, $\mathrm{Na}_{0.27} \mathrm{MnO}_{2}$ exhibits an excellent cycle stability up to 5000 cycles without obvious capacity loss, as well as nearly $100 \%$ coulombic efficiency and high energy efficiency at various current densities (Fig. 4e). Figure $4 \mathrm{f}$ compares the energy and power performance of $\mathrm{Na}_{0.27} \mathrm{MnO}_{2}$ materials with several aqueous or non-aqueous EES devices, including Panasonic (17500) Li-ion battery ${ }^{42}, \alpha-\mathrm{MnO}_{2}, \delta-\mathrm{MnO}_{2}$ or amorphous birnessites $32,43-45$, and tunnel-structured $\mathrm{Na}_{0.44} \mathrm{MnO}_{2}$ and $\mathrm{O} 3$ type $\mathrm{Na}_{\mathrm{x}} \mathrm{MnO}_{2}{ }^{39,46}$. Notably, energy and power densities of our reported system were obtained after 5000 galvanostatic cycles, higher than those found in commercial products and recent literature. Comparisons between current works with other Mn-based electrode materials in aqueous storage are summarized in Supplementary Table $7^{43,46-48}$.

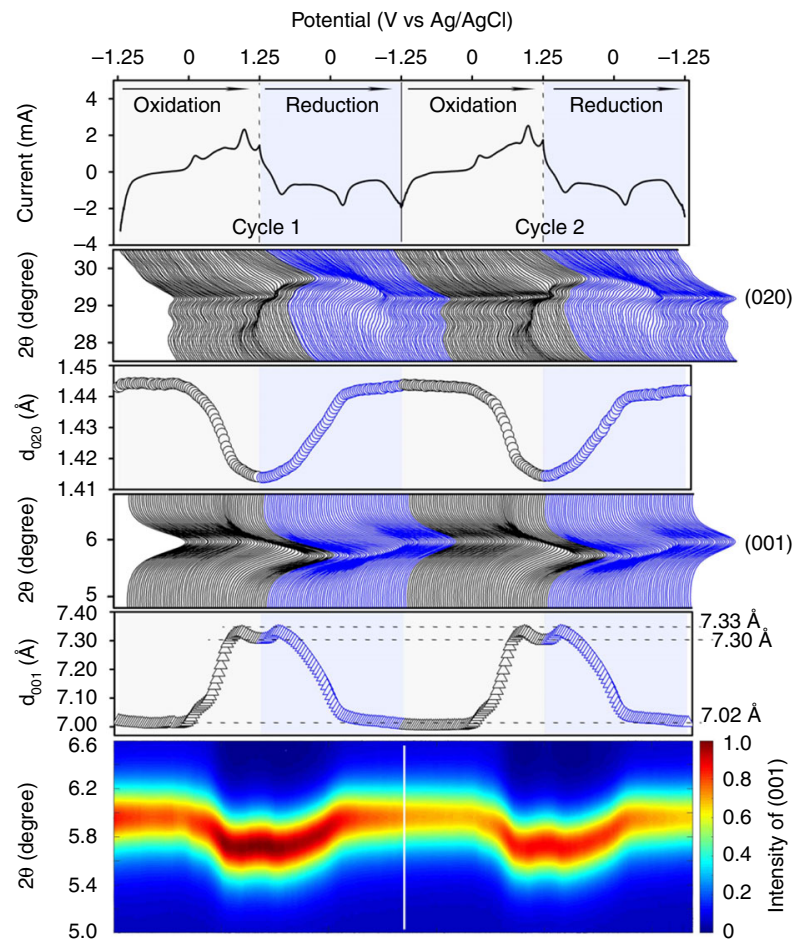

Fig. 5 In situ XRD characterization of $\mathrm{Na}_{0.27} \mathrm{MnO}_{2}$. Two $\mathrm{CV}$ scans were conducted between $-1.25 \mathrm{~V}$ and $1.25 \mathrm{~V}$ at a scan rate of $0.75 \mathrm{mV} \mathrm{s}^{-1}$, showing the changes of $d$-spacing for (001) basal diffraction plane and (020) Bragg diffraction plane and the contour plot peak variation of (001) plane during the charging (black) and discharging (blue) processes

Proton $\left(\mathrm{H}^{+}\right)$insertion has been reported in aqueous EES in mild acidic aqueous electrolytes ${ }^{36,37}$. Current work used a neutral $\mathrm{Na}_{2} \mathrm{SO}_{4}$ electrolyte, thus the $\mathrm{H}^{+}$concentration was very low and $\mathrm{H}^{+}$intercalation may not contribute to overall storage capacity. In addition, $\mathrm{Na}_{0.27} \mathrm{MnO}_{2}$ materials showed continuously increasing capacities during the initial cycling especially at the low current densities. The electrochemical impedance spectroscopy measurements (Supplementary Fig. 21) demonstrate decreasing solution resistance during the initial electrochemical cycling, congruent with I-R drop in the discharge curves (Supplementary Fig. 22). It suggested that the increasing capacities in early cycles can be attributed to the slow building-up of a transport before the electrode reached its best electrochemical condition. Similar behaviours were also observed in $\mathrm{Na}-\mathrm{S}, \mathrm{Na}_{0.67} \mathrm{Ni}_{1 / 6} \mathrm{Co}_{1 / 6} \mathrm{Mn}_{2 / 3} \mathrm{O}_{2}$, and $\mathrm{LiFe}_{0.9} \mathrm{P}_{0.95} \mathrm{O}_{4}{ }^{49-51}$.

Water co-deintercalation during high potential charging. Supplementary Figure 23 shows in situ XRD measurements conducted along with the $\mathrm{CV}$ test at a scan rate of $0.75 \mathrm{mV} \mathrm{s}^{-1}$, where diffraction peaks at the $2 \theta$ angles of $\sim 5.8^{\circ}$ and $\sim 29^{\circ}$ can be attributed to (001) basal diffraction peak and (020) Bragg peak, respectively. As shown in Fig. 5, when the potential increased from $-1.25 \mathrm{~V}$ to $1.25 \mathrm{~V}$ (charging), the (001) peak shifted to a lower $2 \theta$ angle, corresponding to an increasing interlayer distance of (001) plane $\left(\mathrm{d}_{001}\right)$ because the electrostatic repulsion between the $\left[\mathrm{MnO}_{6}\right]$ layers leads to an increase of interlayer spacing upon the removal of Na-ions, whereas (020) Bragg peak shifted to a higher $2 \theta$ angle simultaneously with a decreasing $\mathrm{d}_{020}$ due to the increased fraction of $\mathrm{Mn}^{4+}$ ions that have a smaller radius than $\mathrm{Mn}^{3+}$. During the reduction (from $1.25 \mathrm{~V}$ to $-1.25 \mathrm{~V}$ ), $(001)$ and (020) peaks were restored to the original states. Nearly identical behaviors were also found in the second cycle. $\mathrm{Na}_{0.27} \mathrm{MnO}_{2}$ material showed a $4.4 \%$ change in the $\mathrm{d}_{001}$ spacing of (from $7.33 \AA$ 




Fig. 6 Schematic of Na-ions and water motion during the redox processes. It shows co-deintercalation and co-intercalation of Na-ion and water molecules within the interlayer region of the $\mathrm{Na}_{0.27} \mathrm{MnO}_{2}$ during charging (oxidation) and discharging (reduction) processes

to $7.02 \AA$ ) between fully charged and discharged states, more significant than previously reported $\mathrm{MnO}_{2}$ birnessite (1.7\%) with a potential window of $1.2 \mathrm{~V}$ and a low capacity of $36 \mathrm{mAh} \mathrm{g}^{-1} 27$. The contour plot in Fig. 5 reflects peak shifts of the (001) basal diffraction peak of $\mathrm{Na}_{0.27} \mathrm{MnO}_{2}$ during charging and discharging process. The observed continuous and reversible peak shifting without a staged structural transformation indicates high structural stability of $\mathrm{Na}_{0.27} \mathrm{MnO}_{2}$ during the charging and discharging processes, which explains the good cycle life of $\mathrm{Na}_{0.27} \mathrm{MnO}_{2}$ materials.

In situ XRD also revealed water trafficking, for the first time, along with $\mathrm{Na}$-ions insertion and extraction during the charging and discharging process. Figure 6 shows that when the potential increased from $-1.250 \mathrm{~V}$ to $-0.106 \mathrm{~V}, \mathrm{~d}_{001}$ and the corresponding electrochemical current remained relatively constant, suggesting a non-Faradaic capacitive charge storage process (e.g., desorption of Na-ions from electrode surface) without extrcting $\mathrm{Na}$-ions from interlayers. When the potential increased from $-0.106 \mathrm{~V}$ to $0.914 \mathrm{~V}, \mathrm{~d}_{001}$ increased rapidly from $7.02 \AA$ to $7.33 \AA$, indicating a large amount of $\mathrm{Na}$-ions were extracted from the interlayers, concurrent with the increasing Faradaic current; as the potential continuously increased from $0.914 \mathrm{~V}$ to $1.25 \mathrm{~V}, \mathrm{~d}_{001}$ decreased from $7.33 \AA$ to $7.30 \AA$. Interlayer collpase at higher potential is likely attributed to the removal of structural water along with Na-ion extraction, since a mere Na-ion removal alone would only cause an increase in $\mathrm{d}_{001}$. Notably, such compression at high potential only happened in the interlayer distance (along $c$-direction) because $\mathrm{d}_{020}$ decreased continuously indicating continued oxidation of $\mathrm{Mn}^{3+}$ into $\mathrm{Mn}^{4+}$ when the potential increased from $-0.106 \mathrm{~V}$ to $1.25 \mathrm{~V}$. Although it is possible that when the potential increased from $-0.106 \mathrm{~V}$ to $0.914 \mathrm{~V}$ the extracted Na-ions would also bring structural water out of the interlayer region, it was obvious that weakened electrostatic interaction caused by the Na-ion removal offsets the water removal effect if any, so that the overall interlayer distance still significantly increases. This means that extracted $\mathrm{Na}$-ions at lower anodic potential range (from $-0.106 \mathrm{~V}$ to $0.914 \mathrm{~V}$ ) brought much less (or none) hydrated water molecules out of the interlayer region compared with the ones extracted at higher anodic potential (from $0.914 \mathrm{~V}$ to $1.25 \mathrm{~V}$ ). In other words, hydrated Naions required higher overpotential to be removed from interlayer region than less hydrated ones. It is possible that $\mathrm{O}$ ions (from water) in the solvation shell of the intercalated $\mathrm{Na}$-ions could interact with $\mathrm{Mn}$ ions from $\mathrm{Mn}-\mathrm{O}$ octahedral layer, especially when there are local defects (e.g., anion defect) and $\mathrm{Mn}$ cations are under-coordinated as previously reported interaction between $\mathrm{V}_{2} \mathrm{O}_{5}$ and structural water ${ }^{52}$. Such interaction could increase the energy barrier for Na-ion migration at charging process, and thus a higher overpotential will be needed to extract these hydrated Na-ion from host material. It is also possible that water molecules in the solvation shell of Na-ion could form hydrogen bonding in the interlayer region. This argument is also supported by a recent $\mathrm{X}$-ray and neutron total scattering study of the birnessite materials, where hydrogen bonding among the interlayer water molecule and adjacent $\mathrm{Mn}-\mathrm{O}$ layer oxygen ion was found to play an important role in maintaining the intermediate and long-range stacking of $\mathrm{Mn}-\mathrm{O}$ octahedral layer ${ }^{53}$. Therefore, hydrogen bonding between structural water could also stabilize the Naions inside the interlayer region, thus extraction these hydrated $\mathrm{Na}$-ion out of interlayer region (charging) might become more difficult. Likewise, during the reduction process quite symmetric changes of $d_{001}$ were observed: $d_{001}$ slightly increased from $7.30 \AA$ to $7.33 \AA$ as the potential decreased from $1.25 \mathrm{~V}$ to $0.951 \mathrm{~V}$, and then sharply decreased from $7.33 \AA$ to $7.02 \AA$ as the potential continued to decrease from $0.951 \mathrm{~V}$ to $-0.682 \mathrm{~V}$. This suggests that inserted $\mathrm{Na}$-ions in the higher cathodic potential range (from $1.25 \mathrm{~V}$ to $0.951 \mathrm{~V}$ ) brought more hydrated Na-ions into the interlayer region compared with ones inserted at lower anodic potentials (from $0.998 \mathrm{~V}$ to $-0.682 \mathrm{~V}$ ). Congruent with the observation of the water trafficing during the anodic scan, fully hydrated $\mathrm{Na}$-ions preferred to be inserted into the interlayer region than less hydrated ones during the cathodic scan.

In conventional LIB layered oxide cathodes, a decrease in the $c$-lattice is widely observed at higher degrees of delithiation, even when there is no phase transformation ${ }^{54}$. Recent work on a variety of $\mathrm{LiNi}_{1-x-y} \mathrm{Co}_{x} \mathrm{Mn}_{y} \mathrm{O}_{2}$ (NMC) compounds found the 
a

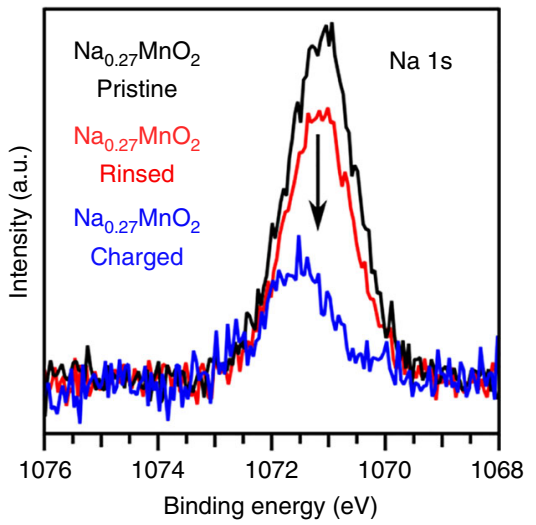

b

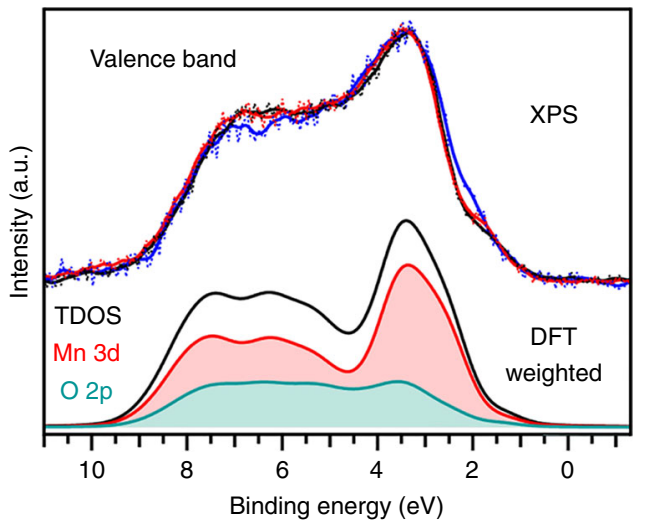

Fig. 7 XPS and DTF analysis of $\mathrm{Na}_{0.27} \mathrm{MnO}_{2}$.XPS measurements. a $\mathrm{Na} 1 \mathrm{~s}$ region for pristine $\mathrm{Na}_{0.27} \mathrm{MnO}_{2}$ powder, $\mathrm{Na}_{0.27} \mathrm{MnO}_{2}$ powder rinsed in the $\mathrm{Na}_{2} \mathrm{SO}_{4}$ electrolyte, and $\mathbf{b}$ valence band of $\mathrm{Na}_{0.27} \mathrm{MnO}_{2}$ electrode charged to $1.25 \mathrm{~V}$ (vs Ag/AgCl). The valence band XPS spectra are compared with DFT calculations of the TDOS and the $\mathrm{Mn} 3 \mathrm{~d}$ and $\mathrm{O} 2 \mathrm{p}$ PDOS for the $\mathrm{Na}_{0.27} \mathrm{MnO}_{2}$ system

onset of this decrease in the c-lattice when around $50-60 \%$ lithium has been removed from the structure with limited dependence on $\mathrm{Ni}, \mathrm{Co}$, or $\mathrm{Mn}$ content ${ }^{55}$. In those LIB cathodes, strong nickel/cobalt-oxygen covalency is expected to facilitate charge transfer from the $\mathrm{O} 2 \mathrm{p}$ orbitals, decreasing the negativecharge on the oxygen ${ }^{56}$. This effectively weakens electrostatic respulsions between neighboring oxygens across the Li-layer leading to a decrease in the interlayer spacing and thereby a decrease in the c-lattice. Upon relithiation, the c-lattice expands and can symetrically match the collapse observed during delithiation ${ }^{55,57}$. Density functional theory (DFT) calculations have shown this effect occurs for the $\mathrm{LiMnO}_{2}$ system and may need to be considered for other Mn(IV)-systems ${ }^{58}$.

We performed XPS measurements for pristine, rinsed, and charged $\mathrm{Na}_{0.27} \mathrm{MnO}_{2}$ in conjunction with DFT calculations, shown in Fig. 7. In this case, the charged $\mathrm{Na}_{0.27} \mathrm{MnO}_{2}$ is binderfree, which allowed for increased sensitivity to the $\mathrm{Na}_{0.27} \mathrm{MnO}_{2}$ compound (Supplementary Fig. 24). When charged to $1.25 \mathrm{~V}$, there is a decrease in the intensity of the $\mathrm{Na}$ peak due to the removal of $\mathrm{Na}$-ions from the interlayer (Fig. 7a). The corresponding valence band XPS measurements display only a slight change in the lineshape of the charged electrode compared to the pristine and rinsed samples likely related to the depopulation of states upon the removal of Na-ions. DFT calculations of the total density of states (TDOS) $\mathrm{Na}_{0.27} \mathrm{MnO}_{2}$ system weighted by the $\mathrm{X}$-ray photoionization cross-section ${ }^{6}$ match well with the experimental spectra suggesting these calculations can be used to comment on Mn 3d-O 2p covalency (Fig. 7b). When looking at the weighted $\mathrm{O} 2 \mathrm{p}$ and $\mathrm{Mn} 3 \mathrm{~d}$ partial density of states, we find $\mathrm{O}$ $2 \mathrm{p}$ states contribute at the top of the valence band $(0 \mathrm{eV}$ to $2 \mathrm{eV})$. At $1486 \mathrm{keV}$, the Mn 3d photoionization cross-section is over four times higher than the $\mathrm{O} 2 \mathrm{p}$ state so that in the unweighted DFT calculations the $\mathrm{O} 2 \mathrm{p}$ orbitals are the dominant contribution from 0 to $2 \mathrm{eV}$ (Supplementary Fig. 25), i. e., there is discernable $\mathrm{Mn}-\mathrm{O}$ covalency in the $\mathrm{Na}_{0.27} \mathrm{MnO}_{2}$ so that we may have to consider a decrease in the negative-charge on the oxygen with Na-removal. While this highlights the role $\mathrm{Mn}-\mathrm{O}$ covalency may play in Na-removal, we believe the water trafficking (codeintercalation with $\mathrm{Na}$-ion) at high potentials remains the primary factor in the observed shrinkage of the interlayer for $\mathrm{Na}_{0.27} \mathrm{MnO}_{2}$ for the following reasons. Firstly, compared to the LIB electrodes with an interlayer spacing $<3 \AA$, the $\mathrm{Na}_{0.27} \mathrm{MnO}_{2}$ system has an interlayer spacing of $7.1 \AA$. Thus, the oxygenoxygen interaction between adjacent $\left[\mathrm{MO}_{6}\right]$ layers in birnessite, which is inversely correlated to the square of the interlayer distance $\left(\propto \frac{1}{r^{2}}\right.$ where $r$ is the distance between neighboring oxygen) is relatively weak compared to the NMC compounds. Moreover, the structural water within the interlayer of $\mathrm{Na}_{0.27} \mathrm{MnO}_{2}$ birnessite provides a "screening" effect that further weakens the O-O interaction, well described by Debye-Huckel theory.

Different from $c$-lattice collapse in charged LIB layered oxide, where the irreversible and large lattice collapse (up to 5\%) results in the pulverization of electrode material and impairs their full utilization for Li-ion storage, the reversible co-deintercalation of structual water in $\mathrm{Na}_{0.27} \mathrm{MnO}_{2}$ benefits $\mathrm{Na}$-ion storage. Notably, repetitive insertion and extraction of cations and thus drastic changes of the interlayer distance during prolonged cycling can cause the degradation of the electrode material. Figure 6 showed that as the $c$-lattice contracted, the $b$-lattice continue to decrease $\left(\mathrm{d}_{001}\right.$ and $\mathrm{d}_{020}$ decreased). This indicates that the codeintercalation of water molecules along with $\mathrm{Na}$-ions stabilizes the layered structure against further expansion of the interlayer distance at higher voltages while sustaining an intensive redox process. To the best of our knowledge, this new safety mechanism has never been reported in aqueous energy storage. Notably, previous investigations of intercalation cations (e.g., $\mathrm{Na}^{+}$and $\mathrm{Mg}^{2+}$ ) in aprotic electrolytes in layered materials have reported a similar water-assisted cation insertion, where insertion kinetics can be greatly improved since a water solvation shell partially shields the charge of cations within the cation/water cointercalation compound ${ }^{59-63}$.

Supplementary Figure 26 shows $\mathrm{Na}_{0.19} \mathrm{MnO}_{2}$ (synthesized via thermal decomposition of $\mathrm{NaMnO}_{4}$ materials at $800^{\circ} \mathrm{C}$ ) had a lower amount of structural water compared with hydrated $\mathrm{Na}_{0.27} \mathrm{MnO}_{2}$ materials, evidenced by its narrower interlayer distance $(0.713 \mathrm{~nm}$ vs $0.719 \mathrm{~nm}$ ) as XRD showed (Supplementary Fig. 26). More importantly, the half-cell CP measurements showed that less hydrated $\mathrm{Na}_{0.19} \mathrm{MnO}_{2}$ birnessite had an inferior electrochemical performance to the hydrated $\mathrm{Na}_{0.27} \mathrm{MnO}_{2}$ in term of discharge capacity, rate performance and cycle life (Supplementary Fig. 27). For example, the hydrated $\mathrm{Na}_{0.27} \mathrm{MnO}_{2}$ showed a much higher discharge capacity (138 $\left.\mathrm{mAh} \mathrm{g}^{-1}\right)$ compared with less hydrated $\mathrm{Na}_{0.19} \mathrm{MnO}_{2} \quad\left(60 \mathrm{mAh} \mathrm{g}^{-1}\right)$. Moreover, at a current density of $1 \mathrm{Ag}^{-1}, \mathrm{Na}_{0.27} \mathrm{MnO}_{2}$ also demonstrated higher discharge capacities and higher capacity retention compared with $\mathrm{Na}_{0.19} \mathrm{MnO}_{2}$ throughout the first 100 charge and discharge cycles ( $53 \%$ vs $29 \%$ at 50 th cycle and $35 \%$ vs $22 \%$ at 100 th cycle), while maintaining comparable coulombic efficiencies. Thus, it is evident that structural water cointercalation with $\mathrm{Na}$-ions plays promotional roles in electrochemical performance. 
a

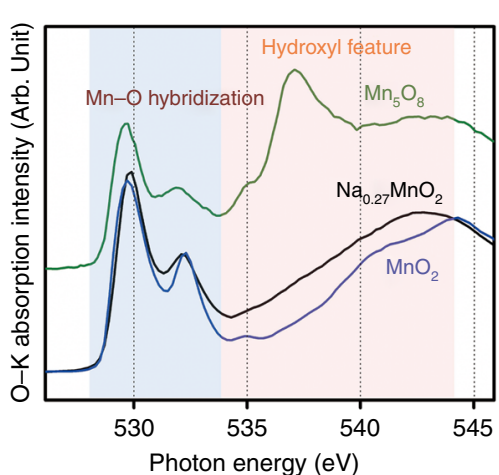

c



b

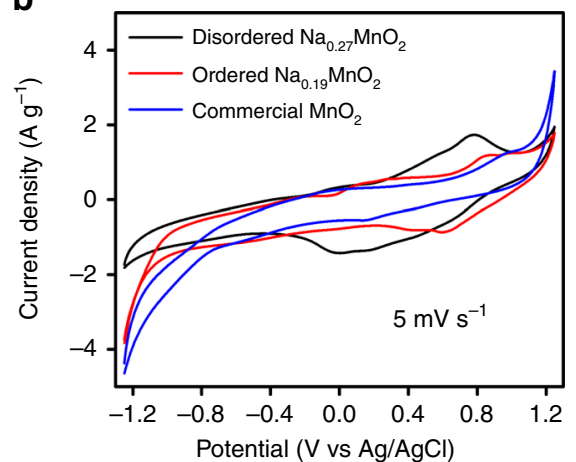

d

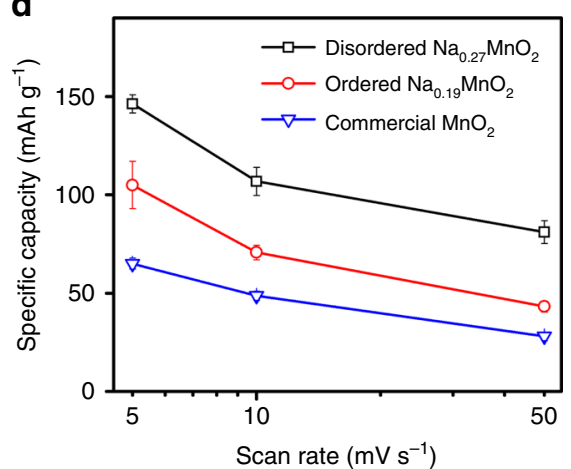

Fig. 8 The effects of disorder structure on the potential window. a Oxygen K-edge sXAS of electrochemically cycled $\mathrm{Na}_{0.27} \mathrm{MnO}_{2}, \mathrm{Mn}_{5} \mathrm{O}_{8}$ and commercial $\mathrm{MnO}_{2}$ materials; $\mathbf{b} \mathrm{CV}$ scans of disordered $\mathrm{Na}_{0.27} \mathrm{MnO}_{2}$, ordered $\mathrm{Na}_{0.19} \mathrm{MnO}_{2}$ and commercial $\mathrm{MnO}_{2}$ materials at the scan rate of $5 \mathrm{mV} \mathrm{s}^{-1}$ in a $2.5 \mathrm{~V}$ potential window in half-cell; c calculated Tafel slopes of HER and OER at the scan rate of $5 \mathrm{mV} \mathrm{s}^{-1}$; $\mathbf{d}$ Specific capacities at the scan rate of 5 , 10 and $50 \mathrm{mVs}^{-1}$

The disordered structure widens the voltage window. Although $\mathrm{Mn}_{5} \mathrm{O}_{8}$ and $\mathrm{Na}_{0.27} \mathrm{MnO}_{2}$ materials showed a $2.5 \mathrm{~V}$ stable voltage window for aqueous $\mathrm{Na}$-ion storage (Supplementary Figs. 10, 28), the mechanisms underlying their high resistance toward HER and OER were completely different. Figure 8 a shows that O-K sXAS spectra of $\mathrm{Na}_{0.27} \mathrm{MnO}_{2}$ and $\mathrm{Mn}_{5} \mathrm{O}_{8}$ have similar sharp features below $534 \mathrm{eV}$ from the hybridization between the $\mathrm{O} 2 \mathrm{p}$ band and $\mathrm{Mn} 3 \mathrm{~d}$ states. However, only the $\mathrm{Mn}_{5} \mathrm{O}_{8}$ material showed distinct fingerprint water-features at the 535 and $537 \mathrm{eV}$, indicating the formation of a highly ordered hydroxylated interphase on the surface as we reported previously ${ }^{48}$. To understand role of disordered structure in mitigating the water decomposition, we synthesized ordered $\mathrm{Na}_{0.19} \mathrm{MnO}_{2}$ birnessite via thermal decomposition of $\mathrm{NaMnO}_{4}$ materials at $800{ }^{\circ} \mathrm{C}$ and conducted the Tafel analysis for hydrogen evolution reaction (HER) and oxygen evolution reaction (OER) on disordered $\mathrm{Na}_{0.27} \mathrm{MnO}_{2}$, ordered $\mathrm{Na}_{0.19} \mathrm{MnO}_{2}$ and commercial $\mathrm{MnO}_{2}$ materials in a $0.1 \mathrm{M} \mathrm{Na}_{2} \mathrm{SO}_{4}$ electrolyte. XRD and X-ray PDF were conducted to compare the structural difference of three materials (Supplementary Fig. 2930, Supplementary Tables 8-10), showing that disordered $\mathrm{Na}_{0.27} \mathrm{MnO}_{2}$ had a triclinic (C-1) birnessite structure. Though disordered $\mathrm{Na}_{0.27} \mathrm{MnO}_{2}$ and ordered $\mathrm{Na}_{0.19} \mathrm{MnO}_{2}$ both show the birnessite layered structure, $\mathrm{Na}_{0.27} \mathrm{MnO}_{2}$ has a smaller crystalline size and a shorter coherence length (Supplementary Fig. 29b) compared to $\mathrm{Na}_{0.19} \mathrm{MnO}_{2}$. On the other hand, commercial $\mathrm{MnO}_{2}$ showed a highly crystalline and ordered $\beta-\mathrm{MnO}_{2}$ phase. Supplementary Figure 30 demonstrated the difference of local structures between disordered $\mathrm{Na}_{0.27} \mathrm{MnO}_{2}$ and ordered $\mathrm{Na}_{0.19} \mathrm{MnO}_{2}$ birnessite and commercial $\mathrm{MnO}_{2}$, where the former showed a more disordered lattice structure.

Figure $8 \mathrm{~b}$ shows the CVs of disordered $\mathrm{Na}_{0.27} \mathrm{MnO}_{2}$, ordered $\mathrm{Na}_{0.19} \mathrm{MnO}_{2}$ and commercial $\beta-\mathrm{MnO}_{2}$ and a scan rate of $5 \mathrm{mV} \mathrm{s}{ }^{-1}$
(CVs tested at other scan rates are shown in Supplementary Fig. 31). Though all three materials were tested in a $2.5 \mathrm{~V}$ potential window, ordered $\mathrm{Na}_{0.19} \mathrm{MnO}_{2}$ and commercial $\beta-\mathrm{MnO}_{2}$ materials displayed obvious gas evolution features at lower and higher potential ranges. The Tafel analysis showed that disordered $\mathrm{Na}_{0.27} \mathrm{MnO}_{2}$ displayed a much weaker HER current at potentials up to $-1.25 \mathrm{~V}$ (overpotential of $0.63 \mathrm{~V}$ towards HER) and higher Tafel slopes at various scan rates (Fig. 8c, Supplementary Fig. 31), suggesting sluggish HER kinetics. It is notable that three materials were inactive towards OER even at a potential of $1.25 \mathrm{~V}$ (overpotential of $0.63 \mathrm{~V}$ towards OER), however, only disordered $\mathrm{Na}_{0.27} \mathrm{MnO}_{2}$ has high overpotential for both HER and OER, suggesting that the disordered nature leads to high resistance to the gas evolution reactions, thus a kinetically stable potential window of $2.5 \mathrm{~V}$. Although ordered $\mathrm{Na}_{0.19} \mathrm{MnO}_{2}$ and commercial $\beta-\mathrm{MnO}_{2}$ materials showed a great capacity enhancement at a lower potential range close to $-1.25 \mathrm{~V}$, probably benefiting from hydrogen insertion, disordered $\mathrm{Na}_{0.27} \mathrm{MnO}_{2}$ still showed much superior capacities at all tested scan rates. The inferior capacities from ordered $\mathrm{Na}_{0.19} \mathrm{MnO}_{2}$ and commercial $\beta-\mathrm{MnO}_{2}$ might be due to the parasitic gas evolution reactions especially HER that degraded the electrode and causes capacity loss at prolonged cycles. Previous DFT calculations demonstrated that the thermodynamically unstable edge sites of the layered transition-metal dichalcogenides nanocrystals were catalytically active for $\mathrm{HER}^{47}$. Previous studies showed that HER current was proportional to the length of edges rather than the coverage area of catalysts ${ }^{64,65}$, but these catalytically active sites were located on the thermodynamically unstable planes (edges of the layers), which are difficult to be exposed preferentially ${ }^{66,67}$. In this study, disordered $\mathrm{MnO}_{2}$ layered structures have highly exposed (001) planes that are thermodynamically stable plane but 
catalytically inert, while the ordered $\mathrm{Na}_{0.19} \mathrm{MnO}_{2}$ birnessite possesses a large grain size with a long coherent length, therefore the edges of the layers that are more active toward gas evolution are likely exposed.

\section{Discussion}

In this work, we have integrated detailed structural analysis with electrochemical measurements to understand the observed high capacity and good structural stability found in the disordered and Na-rich $\mathrm{Na}_{0.27} \mathrm{MnO}_{2}$ birnessite layered materials. In situ XRD has revealed the role of water co-deintercalation in mitigating interlayer expansion during the high potential charging. Investigations of solvent co-intercalation properties in other layered materials will be useful in designing high capacity rechargeable aqueous batteries. In addition to water trafficking, our results also manifest the promotional effects of the disordered structure on aqueous $\mathrm{Na}$-ion storage: disordered $\mathrm{Na}_{0.27} \mathrm{MnO}_{2}$ structure allows continuous and smooth structural evolution during the charging and discharging processes without phase transitions and possesses highly exposed (001) planes with low density of active edge sites for gas evolution reactions, and thus yields a large aqueous $\mathrm{Na}-$ ion storage capacity and long cycling life. The reported results have provided the insight underlying the promotional roles of structural water and disordered electrode structure for aqueous $\mathrm{Na}$-ion storage. Especially, the structural water trafficking at high potential charging discovered here may provide a fundamental leap forward in current understanding how water molecules stabilize the electrode structure during redox processes.

\section{Methods \\ Material synthesis. $\mathrm{Mn}_{3} \mathrm{O}_{4}$ nanoparticles were first synthesized via a solution} phase method. In a typical synthesis, $\mathrm{MnCl}_{2} \cdot 4 \mathrm{H}_{2} \mathrm{O}(0.7 \mathrm{~g}$, Alfa Aesar, $99 \%$ metals basis) was fully dissolved by deionized water ( $140 \mathrm{~mL}, 18.2 \mathrm{M} \Omega$; Millipore, Inc.) in a $500 \mathrm{~mL}$ flask under vigorous stirring at room temperature. The aqueous solution of $\mathrm{NaOH}$ (Alfa Aesar, $99.98 \%$ metals basis) with a concentration of $0.123 \mathrm{~g} \mathrm{~mL}^{-1}$ was injected at a rate of $0.167 \mathrm{~mL} \mathrm{~min}^{-1}$ for $50 \mathrm{~min}$ using an automatic syringe (HSW Inc.). After injection, the mixture continuously reacted for another $30 \mathrm{~min}$ till dark brown precipitate was formed. The resulting product was separated by centrifuging and then washed by deionized water and ethanol consecutively. The obtained products $\left(\mathrm{Mn}_{3} \mathrm{O}_{4}\right.$ nanoparticles) were finally vacuum-dried. In the synthesis of sodium-manganese oxides, $\mathrm{NaOH}$ (Alfa Aesar, $99.99 \%$ metals basis) and $100 \mathrm{mg} \mathrm{Mn}_{3} \mathrm{O}_{4}$ nanoparticles were grounded using a mortar and pestle with the molar ratios of $0.5,1,1.5,2$, and 4 , respectively. The resulting mixture of $\mathrm{NaOH}$ and $\mathrm{Mn}_{3} \mathrm{O}_{4}$ was heated in a tube furnace (Thermal Scientific, Inc.) in open air at $270{ }^{\circ} \mathrm{C}$ for $6 \mathrm{~h}$. The obtained solids were thoroughly washed with deionized water to remove the possible $\mathrm{NaOH}$ residual and vacuum-dried for overnight. Ordered $\mathrm{Na}_{0.19} \mathrm{MnO}_{2}$ birnessite was synthesized via thermal decomposition of $\mathrm{NaMnO}_{4}$ at $800^{\circ} \mathrm{C}$ for $12 \mathrm{~h}$, and then washed by deionized water and ethanol, and dried in vacuum. The $\mathrm{MnO}_{2}$ birnessite with low sodium concentration $\mathrm{Na}_{0.13} \mathrm{MnO}_{2}$ was synthesized via a wet chemistry method. Aqueous $\mathrm{MnCl}_{2}\left(5 \mathrm{mg} \mathrm{mL}^{-1}\right)$ precursor was injected into $20 \mathrm{~mL} \mathrm{NaOH}$ solution with a concentration of $5.7 \mathrm{mg} \mathrm{mL}^{-1}$ at the rate of $0.167 \mathrm{~mL} \mathrm{~min}^{-1}$ for $1 \mathrm{~h}$, and the obtained product was vacuum-dried after washed by deionized water and ethanol. And then the solids were annealed in air at $270{ }^{\circ} \mathrm{C}$ for $6 \mathrm{~h}$

Material characterizations. Inductively coupled plasma mass spectrometry (ICPMS) was used to identify the elemental ratios of materials. Sample aliquots were digested in mixed concentrated $\mathrm{HCl}-\mathrm{HNO}_{3}$ solution and then transferred into $\mathrm{HNO}_{3}$ solution for dilution in $2 \% \mathrm{HNO}_{3}$ and introduction into the $\mathrm{Nu}$ instruments AttoM high resolution ICP-MS. Standards of known concentrations were used to correct for drift and within-instrument elemental fractionation. Triplicate runs of each sample allowed for the determination of the precision of each sample. Energy dispersive X-ray spectroscopy (EDXS) was conducted for elemental analysis by an Amray 3300FE field emission SEM with a PGT Imix-PC microanalysis system at the University of New Hampshire. Thermogravimetric analysis (TGA) was measured on a Mettler-Toledo instrument at the University of New Hampshire. Regular transmission electron microscopy (TEM) images were collected on Zeiss/LEO 922 Omega TEM at the University of New Hampshire. X-ray photoelectron spectroscopy (XPS) was measured using Thermo Scientific K-Alpha instrument at Harvard University.

Half-cell test. Cyclic voltammetry (CV) measurements of sodium-manganese oxide were conducted using a three-electrode half-cell powered by $\mathrm{CHI} 660 \mathrm{~d}$ single channel electrochemical workstation. The three-electrode system contained a glassy carbon rotating disc electrode (Pine Instrument) as the working electrode, platinum wire and silver-silver chloride $(\mathrm{Ag} / \mathrm{AgCl})$ electrode as counter and reference electrodes, respectively. The ink material was prepared by grinding mixture of $7 \mathrm{mg}$ sodium-manganese oxide and $3 \mathrm{mg}$ carbon black (Alfa Aesar, $>99.9 \%$ ). The resulting mixture was mixed with deionized water to make an ink solution of $0.5 \mathrm{mg} \mathrm{mL}^{-1}$. The resulting solution was subsequently sonicated until the materials were homogeneously dispersed. In a typical half-cell measurement, $10 \mu \mathrm{L}$ suspension containing $3.5 \mu \mathrm{g}$ sodium-manganese oxide and $1.5 \mu \mathrm{g}$ carbon black was drop-cast onto the glassy carbon disc electrode $(0.5 \mathrm{~cm}$ in diameter $)$ and vacuumdried. The CV measurements of electrodes were conducted in a $250 \mathrm{~mL}$ flat-bottom flask containing $100 \mathrm{~mL}$ argon-purged $\mathrm{Na}_{2} \mathrm{SO}_{4}$ aqueous electrolyte $(0.1 \mathrm{M})$ at a rotating rate of $500 \mathrm{rpm}$. The $\mathrm{CV}$ data were obtained within an applied potential range from $-1.25 \mathrm{~V}$ to $1.25 \mathrm{~V}$ (vs $\mathrm{Ag} / \mathrm{AgCl}$ ) for three cycles, and the third $\mathrm{CV}$ cycle was used for the calculation of storage capacity. The CP measurements of $\mathrm{Na}_{0.27} \mathrm{MnO}_{2}$ in a three-electrode half-cell was also conducted at the currrent densities from $0.3 \mathrm{Ag} \mathrm{g}^{-1}$ to $2.0 \mathrm{~A} \mathrm{~g}^{-1}$ with potential from $-0.75 \mathrm{~V}$ to $1.25 \mathrm{~V}$ (vs Ag/ AgCl). $\mathrm{Na}_{0.27} \mathrm{MnO}_{2}$ was charged to $1.25 \mathrm{~V}$ (vs $\mathrm{Ag} / \mathrm{AgCl}$ ) from open circuit voltage in $0.5 \mathrm{M} \mathrm{Na}_{2} \mathrm{SO}_{4}$ solution with a scan rate of $1 \mathrm{mV} \mathrm{s}^{-1}$ by using $\mathrm{CV}$ in half-cell, and then discharged to $-1.25 \mathrm{~V}$. The charged and dischaged samples were washed and colloected for ex-situ XPS measurements.

Diffusivity measurements. The diffusivity measurements were tested in a typical half-cell setting as described above, except 40 ug active materials sodiummanganese oxides was loaded on working electrode and $0.25 \mathrm{M} \mathrm{Na}_{2} \mathrm{SO}_{4}$ was used as the electrolyte. A constant negative current pulse of $1 \mathrm{uA}$ was first applied to the working electrode and was held for $15 \mathrm{~s}$ to discharge the electrode from the open circuit potential. After that, the working electrode was relaxed and potential changes were collected for another $1000 \mathrm{~s}$.

Potential of zero charge. The potential of zero charge (pzc) of $\mathrm{Na}_{0.27} \mathrm{MnO}_{2}$ materials was estimated using an open circuit voltage (OCV) measurement using a three-electrode cell in a $0.1 \mathrm{M} \mathrm{Na}_{2} \mathrm{SO}_{4}$ electrolyte. Supplementary Figure 32 shows that the initial potential of the electrode was $0.47 \mathrm{~V}$ ( $\mathrm{vs} \mathrm{Ag} / \mathrm{AgCl}$ ), slowly increased to a rather stable value of $0.50 \mathrm{~V}$ after $2 \mathrm{~h}$ without an external field. In this context, pzc of $\mathrm{Na}_{0.27} \mathrm{MnO}_{2}$ materials should be around $0.5 \mathrm{~V}$ vs. $\mathrm{Ag} / \mathrm{AgCl}$. As a higher (or lower) external potential is applied, the materials will be oxidized (or reduced) by $\mathrm{Na}$-ion extraction (or insertion).

Full-cell test. Symmetric two-electrode full-cells with $\mathrm{Na}_{0.27} \mathrm{MnO}_{2}$ electrodes were assembled and measured to characterize the energy/power performance and the long cycle stability as well. Electrodes were made by drop casting the slurry containing $\sim 5 \mathrm{mg} \mathrm{Na}_{0.27} \mathrm{MnO}_{2}$ and $1.25 \mathrm{mg}$ carbon black as a mass ratio of $4: 1$ on Toray carbon paper (E-Tek, Inc., $1.5 \mathrm{~cm}$ in diameter). The resulting electrodes were weighed with an accurate mass loading of active material after vacuum-dried overnight. Two symmetric electrodes were separated by cellulose-based filter paper (Whatman), and $150 \mu \mathrm{L} \mathrm{Na} \mathrm{SO}_{4}$ aqueous solution (1 M) was used as the electrolyte. The cell stack of electrodes and separator were tightened by stainless plate and compression spring to ensure good electrical contact and then assembled in the split button-cells (model: EQ-STC, MTI Corp.). Galvanostatic charge and discharge measurements of symmetric full-cells were conducted on the battery analyzer (model: B-TG, Arbin Instruments) within $2.5 \mathrm{~V}$ potential window for $5000 \mathrm{cycles}$ at the constant current densities of $1,2,5$, and $10 \mathrm{Ag}^{-1}$. All the electrochemical calculations are provided in the supporting information. Toray paper was used as current collect for symmetric full-cell measurements and stable in $2.5 \mathrm{~V}$ without obvious generation of hydrogen (Supplementary Fig. 17).

Electrochemical impedance measurements. Electrochemical impedance spectroscopy (EIS) measurements were conducted after each charge and discharge cycle in full cell at the open circuit potential with a perturbation of $5 \mathrm{mV}$ and frequency range from 0.1 to $100 \mathrm{kHz}$, and the Nyquist plots were collected.

X-ray and neutron scattering characterizations. X-ray diffraction measurements were conducted at Beamline 17-BM-B at the Advanced Photon Source at the Argonne National Laboratory with a wavelength of $\lambda=0.72768 \AA$. In situ XRD of electrochemical half-cell measurements were conducted in a home-made cell consisted of thin carbon paper (E-Tek, Inc.) as working electrode, platinum wire and micro $\mathrm{Ag} / \mathrm{AgCl}$ electrode as counter and reference electrodes, respectively. The $\mathrm{Na}_{2} \mathrm{SO}_{4}$ aqueous electrolyte $(1 \mathrm{M})$ was used as the electrolyte. The suspension of a mixture of $\mathrm{Na}_{0.27} \mathrm{MnO}_{2}$ and carbon black was drop-cast on the thin carbon paper and then dried naturally in air. The cellulose-based filter paper was used as a separator. The cell was then assembled for X-ray measurements. In situ XRD tests were performed during $\mathrm{CV}$ scans from $-1.25 \mathrm{~V}$ to $1.25 \mathrm{~V}$ (vs $\mathrm{Ag} / \mathrm{AgCl}$ ) at the scan rates of $0.75 \mathrm{mV} \mathrm{s}^{-1}$. GSAS-II software was used to analyze the structural changes during the charge and discharge processes. The X-ray total scattering experiment was also conducted at Beamline 17-BM-B using a wavelength of $0.24116 \AA$. The total neutron scattering experiment was conducted at the Nanoscale-Ordered Materials Diffractometer (NOMAD) beamline at Spallation Neutron Source at Oak 
Ridge National Laboratory. The atmoic Pair Distribution Function (PDF) analysis was conducted using PDFgui software.

Theoretical methods. Density functional theory (DFT) calculations were performed using the WIEN2k software package, which uses full potential and linearized augmented plane waves with local orbitals (LAPW + lo) to self consistently solve the Kohn-Sham equations ${ }^{61}$. The generalized gradient approximation of Perdew, Burke, and Ernzerhof (GGA-PBE) was used for the exchange and correlation energies ${ }^{62}$. The plane-wave cutoff parameters $R_{M T} K_{\max }$ and $G_{\max }$ were selected as 6.5 and 12 , respectively, and the cutoff energy was $-6.0 \mathrm{Ry}$. The $\mathrm{k}$ points of the cell was $(1 \times 12 \times 4)$ and for the $\mathrm{NaMnO}_{2} \cdot \mathrm{H}_{2} \mathrm{O}$.

\section{Data availability}

The authors declare that the data supporting the findings of this study are available within the paper and its supplementary information files.

Received: 12 February 2018; Accepted: 12 October 2019;

Published online: 31 October 2019

\section{References}

1. Yabuuchi, N. et al. P2-type $\mathrm{Na}_{\mathrm{x}}\left[\mathrm{Fe}_{1 / 2} \mathrm{Mn}_{1 / 2} \mathrm{O}\right]_{2}$ made from earth-abundant elements for rechargeable Na batteries. Nat. Mater. 11, 512-517 (2012).

2. Kim, H. et al. Aqueous rechargeable $\mathrm{Li}$ and $\mathrm{Na}$ ion batteries. Chem. Rev. 114, 11788-11827 (2014).

3. Wessells, C. D., Huggins, R. A. \& Cui, Y. Copper hexacyanoferrate battery electrodes with long cycle life and high power. Nat. Commun. 2, 5 (2011).

4. Pasta, M., Wessells, C. D., Huggins, R. A. \& Cui, Y. A high-rate and long cycle life aqueous electrolyte battery for grid-scale energy storage. Nat. Commun. 3, 7 (2012).

5. Pasta, M. et al. Manganese-cobalt hexacyanoferrate cathodes for sodium-ion batteries. J. Mater. Chem. A 4, 4211-4223 (2016).

6. Wang, L. et al. A superior low-cost cathode for a Na-ion battery. Angew. Chem. Int. Ed. 52, 1964-1967 (2013).

7. Song, J. et al. Removal of interstitial $\mathrm{H}_{2} \mathrm{O}$ in hexacyanometallates for a superior cathode of a sodium-ion battery. J. Am. Chem. Soc. 137, 2658-2664 (2015).

8. Lu, Y. H., Wang, L., Cheng, J. G. \& Goodenough, J. B. Prussian blue: a new framework of electrode materials for sodium batteries. Chem. Commun. 48, 6544-6546 (2012).

9. Caballero, A. et al. Synthesis and characterization of high-temperature hexagonal P2- $\mathrm{Na}_{0.6} \mathrm{MnO}_{2}$ and its electrochemical behaviour as cathode in sodium cells. J. Mater. Chem. 12, 1142-1147 (2002).

10. Clement, R. J., Bruce, P. G. \& Grey, C. P. Review- Manganese-based P2-type transition metal oxides as sodium-ion battery cathode materials. J. Electrochem. Soc. 162, A2589-A2604 (2015).

11. Kubota, K., Yabuuchi, N., Yoshida, H., Dahbi, M. \& Komaba, S. Layered oxides as positive electrode materials for Na-ion batteries. MRS Bull. 39, 416-422 (2014).

12. Delmas, C., Fouassier, C. \& Hagenmuller, P. Structural classification and properties of the layered oxides. Phys. B C. 99, 81-85 (1980).

13. Mendiboure, A., Delmas, C. \& Hagenmuller, P. Electrochemical intercalation and deintercalation of NaxMnO2 bronzes. J. Solid State Chem. 57, 323-331 (1985).

14. Doeff, M. M., Peng, M. Y., Ma, Y. P. \& Dejonghe, L. C. Orthorhombic $\mathrm{Na}_{\mathrm{x}} \mathrm{MnO}_{2}$ as a cathode material for secondary sodium and lithium polymer batteries. J. Electrochem. Soc. 141, L145-L147 (1994).

15. Kim, S., Ma, X. H., Ong, S. P. \& Ceder, G. A comparison of destabilization mechanisms of the layered $\mathrm{Na}_{\mathrm{x}} \mathrm{MO}_{2}$ and $\mathrm{Li}_{\mathrm{x}} \mathrm{MO}_{2}$ compounds upon alkali deintercalation. Phys. Chem. Chem. Phys. 14, 15571-15578 (2012).

16. $\mathrm{Li}, \mathrm{X}$. et al. Jahn-teller assisted $\mathrm{Na}$ diffusion for high performance $\mathrm{Na}$ ion batteries. Chem. Mat. 28, 6575-6583 (2016).

17. Tian, M., Gao, Y. R., Wang, Z. X. \& Chen, L. Q. Understanding structural stability of monoclinic $\mathrm{LiMnO}_{2}$ and $\mathrm{NaMnO}_{2}$ upon de-intercalation. Phys. Chem. Chem. Phys. 18, 17345-17350 (2016).

18. Choi, Y. \& Liu, P. Understanding of ethanol decomposition on $\mathrm{Rh}(111)$ from density functional theory and kinetic Monte Carlo simulations. Catal. Today 165, 64-70 (2011)

19. Kubota, K., Kumakura, S., Yoda, Y., Kuroki, K. \& Komaba, S. Electrochemistry and solid-state chemistry of $\mathrm{NaMeO}_{2}(\mathrm{Me}=3 \mathrm{~d}$ transition metals). Adv. Energy Mater. 8, 40 (2018).

20. Lee, D. H., Xu, J. \& Meng, Y. S. An advanced cathode for Na-ion batteries with high rate and excellent structural stability. Phys. Chem. Chem. Phys. 15 3304-3312 (2013).
21. Yeager, $\mathrm{M}$. et al. Highly efficient $\mathrm{K}_{0.15} \mathrm{MnO}_{2}$ birnessite nanosheets for stable pseudocapacitive cathodes. J. Phy. Chem. C. 116, 20173-20181 (2012).

22. $\mathrm{Qu}, \mathrm{Q}$. et al. Electrochemical performance of $\mathrm{MnO}_{2}$ nanorods in neutral aqueous electrolytes as a cathode for asymmetric supercapacitors. J. Phy. Chem. C. 113, 14020-14027 (2009).

23. Wang, J., Zhang, G. \& Zhang, P. Layered birnessite-type $\mathrm{MnO}_{2}$ with surface pits for enhanced catalytic formaldehyde oxidation activity. J. Mater. Chem. A 5, 5719-5725 (2017).

24. Zhu, H. T. et al. Birnessite-type $\mathrm{MnO}_{2}$ nanowalls and their magnetic properties. J. Phy. Chem. C. 112, 17089-17094 (2008).

25. Cai, J., Liu, J. \& Suib, S. L. Preparative parameters and framework dopant effects in the synthesis of layer-structure birnessite by air oxidation. Chem. Mater. 14, 2071-2077 (2002).

26. Brousse, T., Toupin, M. \& Belanger, D. A hybrid activated carbon-manganese dioxide capacitor using a mild aqueous electrolyte. J. Electrochem. Soc. 151, A614-A622 (2004).

27. Athouel, L. et al. Variation of the $\mathrm{MnO}_{2}$ birnessite structure upon charge/ discharge in an electrochemical supercapacitor electrode in aqueous $\mathrm{Na}_{2} \mathrm{SO}_{4}$ electrolyte. J. Phys. Chem. C. 112, 7270-7277 (2008).

28. Liu, Y. et al. High-performance aqueous sodium-ion batteries with $\mathrm{K}_{0.27} \mathrm{MnO}_{2}$ cathode and their sodium storage mechanism. Nano Energy 5, 97-104 (2014).

29. Suo, L. M. et al. "Water-in-salt" electrolyte enables high-voltage aqueous lithium-ion chemistries. Science 350, 938-943 (2015).

30. Xu, K. \& Wang, C. S. Widening voltage windows. Nat. Energy 1, 16161 (2016)

31. Yamada, Y. et al. Hydrate-melt electrolytes for high-energy-density aqueous batteries. Nat. Energy 1, 16129 (2016).

32. Peng, L. et al. Ultrathin two-dimensional $\mathrm{MnO}_{2}$ /graphene hybrid nanostructures for high-performance, flexible planar supercapacitors. Nano Lett. 13, 2151-2157 (2013).

33. Yeager, M. P. et al. Pseudocapacitive hausmannite nanoparticles with (101) facets: synthesis, characterization, and charge-transfer mechanism. ChemSusChem 6, 1983-1992 (2013).

34. Chen, R., Zavalij, P. \& Whittingham, M. S. Hydrothermal synthesis and characterization of $\mathrm{K}_{\mathrm{x}} \mathrm{MnO}_{2} \cdot \mathrm{yH}_{2} \mathrm{O}$. Chem. Mater. 8, 1275-1280 (1996).

35. Park, Y. J. \& Doeff, M. A. Synthesis and electrochemical characterization of $\mathrm{M}_{2} \mathrm{Mn}_{3} \mathrm{O}_{8}(\mathrm{M}=\mathrm{Ca}, \mathrm{Cu})$ compounds and derivatives. Solid State Ion-. 177, 893-900 (2006).

36. Pan, H. et al. Reversible aqueous zinc/manganese oxide energy storage from conversion reactions. Nat. Energy 1, 16039 (2016).

37. Sun, W. et al. $\mathrm{Zn} / \mathrm{MnO}_{2}$ battery chemistry with $\mathrm{H}^{+}$and $\mathrm{Zn}^{2+}$ coinsertion. J. Am. Chem. Soc. 139, 9775-9778 (2017).

38. Huang, J. et al. Polyaniline-intercalated manganese dioxide nanolayers as a high-performance cathode material for an aqueous zinc-ion battery. Nat. Commun. 9, 2906 (2018)

39. Li, Z., Young, D., Xiang, K., Carter, W. C. \& Chiang, Y.-M. Towards high power high energy aqueous sodium-ion batteries: the $\mathrm{NaTi}_{2}\left(\mathrm{PO}_{4}\right)_{3} /$ $\mathrm{Na}_{0.44} \mathrm{MnO}_{2}$ system. Adv. Energy Mater. 3, 290-294 (2013).

40. Lee, J. et al. Reversible $\mathrm{Mn}^{2+} / \mathrm{Mn}^{4+}$ double redox in lithium-excess cathode materials. Nature 556, 185-190 (2018).

41. Liu, T. C., Pell, W. G., Conway, B. E. \& Roberson, S. L. Behavior of molybdenum nitrides as materials for electrochemical capacitors: comparison with ruthenium oxide. J. Electrochem. Soc. 145, 1882-1888 (1998).

42. Nagasubramanian, G., Jungst, R. G. \& Doughty, D. H. Impedance, power, energy, and pulse performance characteristics of small commercial Li-ion cells. J. Power Sources 83, 193-203 (1999).

43. Wu, Z.-S. et al. High-energy $\mathrm{MnO} 2$ nanowire/graphene and graphene asymmetric electrochemical capacitors. ACS Nano 4, 5835-5842 (2010).

44. $\mathrm{He}, \mathrm{Y}$. et al. Freestanding three-dimensional graphene $/ \mathrm{MnO}_{2}$ composite networks as ultralight and flexible supercapacitor electrodes. ACS Nano 7 , 174-182 (2013).

45. Zhang, D., Zhang, Y., Luo, Y. \& Chu, P. K. Highly porous honeycomb manganese oxide@carbon fibers core-shell nanocables for flexible supercapacitors. Nano Energy 13, 47-57 (2015).

46. Hou, Z., Li, X., Liang, J., Zhu, Y. \& Qian, Y. An aqueous rechargeable sodium ion battery based on a $\mathrm{NaMnO}_{2}-\mathrm{NaTi}_{2}\left(\mathrm{PO}_{4}\right)_{3}$ hybrid system for stationary energy storage. J. Mater. Chem. A 3, 1400-1404 (2015).

47. Brousse, T. et al. Long-term cycling behavior of asymmetric activated carbon/ $\mathrm{MnO}_{2}$ aqueous electrochemical supercapacitor. J. Power Sources 173, 633-641 (2007).

48. Shan, X. Q. et al. Bivalence $\mathrm{Mn} \mathrm{O}_{8}$ with hydroxylated interphase for highvoltage aqueous sodium-ion storage. Nat. Commun. 7, 8 (2016).

49. Yu, X. \& Manthiram, A. Performance enhancement and mechanistic studies of room-temperature sodium-sulfur batteries with a carbon-coated functional nafion separator and a Na2S/activated carbon nanofiber cathode. Chem. Mater. 28, 896-905 (2016).

50. Zheng, J., Yan, P., Kan, W. H., Wang, C. \& Manthiram, A. A spinel-integrated P2-type layered composite: high-rate cathode for sodium-ion batteries. $J$. Electrochem. Soc. 163, A584-A591 (2016). 
51. Kang, B. \& Ceder, G. Battery materials for ultrafast charging and discharging. Nature 458, 190-193 (2009).

52. Charles, D. S. et al. Structural water engaged disordered vanadium oxide nanosheets for high capacity aqueous potassium-ion storage. Nat. Commun. 8, 15520 (2017)

53. Liu, J. et al. Large-scale synthesis and comprehensive structure study of deltaMnO2. Inorg. Chem. 57, 6873-6882 (2018)

54. Radin, M. D. et al. Narrowing the gap between theoretical and practical capacities in Li-ion layered oxide cathode materials. Adv. Energy Mater. 7, 1602888 (2017).

55. Li, W., Asl, H. Y., Xie, Q. \& Manthiram, A. Collapse of $\mathrm{LiNi}_{1-\mathrm{x}-\mathrm{y}} \mathrm{Co}_{\mathrm{x}} \mathrm{Mn}_{\mathrm{y}} \mathrm{O}_{2}$ lattice at deep charge irrespective of nickel content in lithium-ion batteries. $J$. Am. Chem. Soc. 141, 5097-5101 (2019).

56. Kondrakov, A. O. et al. Charge-transfer-induced lattice collapse in Ni-Rich NCM cathode materials during delithiation. J. Phys. Chem. C. 121, 24381-24388 (2017).

57. Grenier, A. et al. Reaction heterogeneity in $\mathrm{LiNi}_{0.8} \mathrm{Co}_{0.15} \mathrm{Al}_{0.05} \mathrm{O} 2$ induced by surface layer. Chem. Mater. 29, 7345-7352 (2017).

58. Scofield J. H. Theoretical photoionization cross sections from 1 to $1500 \mathrm{keV}$. (Lawrence Livermore Laboratory, U.S. Atomic Energy Commission, 1973).

59. Spahr, M. E., Novák, P., Haas, O. \& Nesper, R. Electrochemical insertion of lithium, sodium, and magnesium in molybdenum(VI) oxide. J. Power Sources 54, 346-351 (1995).

60. Levi, E., Gofer, Y. \& Aurbach, D. On the way to rechargeable Mg batteries: the challenge of new cathode materials. Chem. Mater. 22, 860-868 (2010).

61. Sai Gautam, G., Canepa, P., Richards, W. D., Malik, R. \& Ceder, G. Role of structural $\mathrm{H}_{2} \mathrm{O}$ in intercalation electrodes: the case of $\mathrm{Mg}$ in nanocrystalline Xerogel- $\mathrm{V}_{2} \mathrm{O}_{5}$. Nano Lett. 16, 2426-2431 (2016).

62. Lim, S. Y. et al. Lattice water for the enhanced performance of amorphous iron phosphate in sodium-ion batteries. ACS Energy Lett. 2, 998-1004 (2017).

63. Nam, K. W. et al. Critical role of crystal water for a layered cathode material in sodium ion batteries. Chem. Mater. 27, 3721-3725 (2015).

64. Hinnemann, B. et al. Biomimetic hydrogen evolution: $\mathrm{MoS}_{2}$ Nanoparticles as catalyst for hydrogen evolution. J. Am. Chem. Soc. 127, 5308-5309 (2005).

65. Jaramillo, T. F. et al. Identification of active edge sites for electrochemical H2 evolution from $\mathrm{MoS}_{2}$ nanocatalysts. Science 317, 100-102 (2007).

66. Kong, D. et al. Synthesis of $\mathrm{MoS}_{2}$ and $\mathrm{MoSe}_{2}$ films with vertically aligned layers. Nano Lett. 13, 1341-1347 (2013).

67. Kibsgaard, J., Chen, Z., Reinecke, B. N. \& Jaramillo, T. F. Engineering the surface structure of $\mathrm{MoS}_{2}$ to preferentially expose active edge sites for electrocatalysis. Nat. Mater. 11, 963 (2012)

\section{Acknowledgements}

This work was supported by the US Department of Energy (DOE), Office of Science, Basic Energy Sciences under Award \# DE-SC0010286 (X.T., X.S., F.G., D.C.). The research at Binghamton University is partially supported by NSF DMREF-1627583. This research used Beamline 17-BM-B of the Advanced Photon Source, a U.S. Department of Energy (DOE) Office of Science User Facility operated for the DOE Office of Science by Argonne National Laboratory under Contract No. DE-AC02-06CH11357. The Advanced
Light Source is supported by the Director, Office of Science, Office of Basic Energy Sciences, of the U.S. Department of Energy under Contract No. DE-AC02-05CH11231 The neutron scattering experiments were carried out at the Spallation Neutron Source, which is sponsored by the Scientific User Facilities Division, Office of Basic Energy Sciences, US Department of Energy, under Contract No. DE-AC05-00OR22725 with Oak Ridge National Laboratory.

\section{Author contributions}

All authors contributed to the preparation of the manuscript. X.S. contributed to the material synthesis and characterizations, electrochemical experimental measurements and analysis, X-ray analysis. F.G., X.S., and D.S.C contributed to neutron PDF analysis X.S. and W.X. contributed to X-ray measurement. Z.L.H., S.A.R., and L.F.J.P. contributed to XPS and DFT calculations. J.W. and W.Y. contributed to sXAS measurement and analysis. K.P., J.N., and M.F. contributed to the neutron measurements. X.S. and X.T. wrote the manuscript. X.T. contributed to the design of the experiments.

\section{Competing interests}

The authors declare no competing interests.

\section{Additional information}

Supplementary information is available for this paper at https://doi.org/10.1038/s41467 019-12939-3.

Correspondence and requests for materials should be addressed to X.T.

Peer review information Nature Communications thanks Jacob Olchowka and the other, anonymous, reviewer(s) for their contribution to the peer review of this work.

Reprints and permission information is available at http://www.nature.com/reprints

Publisher's note Springer Nature remains neutral with regard to jurisdictional claims in published maps and institutional affiliations.

Open Access This article is licensed under a Creative Commons Attribution 4.0 International License, which permits use, sharing, adaptation, distribution and reproduction in any medium or format, as long as you give appropriate credit to the original author(s) and the source, provide a link to the Creative Commons license, and indicate if changes were made. The images or other third party material in this article are included in the article's Creative Commons license, unless indicated otherwise in a credit line to the material. If material is not included in the article's Creative Commons license and your intended use is not permitted by statutory regulation or exceeds the permitted use, you will need to obtain permission directly from the copyright holder. To view a copy of this license, visit http://creativecommons.org/ licenses/by/4.0/

(C) The Author(s) 2019 